\title{
Trends and variability of snowmelt in China under climate change
}

\author{
Yong Yang ${ }^{1}$, Rensheng Chen ${ }^{1,2}$, Guohua Liu ${ }^{1,3}$, Zhangwen Liu ${ }^{1}$, Xiqiang Wang ${ }^{1}$ \\ ${ }^{1}$ Qilian Alpine Ecology and Hydrology Research Station, Northwest Institute of Eco-Environment and Resources, Chinese \\ Academy of Sciences, Lanzhou 730000, China \\ $5 \quad{ }^{2}$ College of Urban and Environmental Sciences, Northwestern University, Xi'an 710127, China \\ ${ }^{3}$ College of Resources and Environment, University of Chinese Academy of Sciences, Beijing 100049, China \\ Correspondence to: Rensheng Chen (crs2008@1zb.ac.cn)
}

Abstract. Snowmelt is a major fresh water resource, and quantifying snowmelt and its variability under climate change is necessary for planning and management of water resources. Spatiotemporal changes in snow properties in China have drawn wide attention in recent decades; however, country-wide assessments of snowmelt are lacking. Using precipitation and temperature data with a high spatial resolution $(0.5$ seconds, approximately $1 \mathrm{~km})$, this study calculated the monthly snowmelt in China for the 1951-2017 period using a simple temperature index model, and the model outputs were validated using snowfall, snow depth, snow cover extent and snow water equivalent. Precipitation and temperature scenarios developed from five CMIP5 models were used to predict future snowmelt in China under three different representative 15 concentration pathways (RCP) scenarios (RCP2.6, RCP4.5 and RCP8.5). The results showed that the mean annual snowmelt in China from 1951 to 2017 was $2.41 \times 10^{11} \mathrm{~m}^{3}$. The mean annual snowmelts in Northern Xinjiang, Northeast China, and the Tibetan Plateau - China's three main stable snow cover regions - were $0.18 \times 10^{11} \mathrm{~m}^{3}, 0.42 \times 10^{11} \mathrm{~m}^{3}$ and $1.15 \times 10^{11} \mathrm{~m}^{3}$, respectively. From 1951 to 2017, the snowmelt increased significantly in the Tibetan Plateau and decreased significantly in North, Central and Southeast China. In the whole of China, there was a decreasing trend in snowmelt, but this was not statistically significant. The mean annual snowmelt runoff ratios were generally more than $10 \%$ in almost all third-level basins in West China, more than $5 \%$ in third-level basins in North and Northeast China, and less than 2\% in third-level basins in South China. From 1951 to 2017, the annual snowmelt runoff ratios decreased in most third-level basins in China. Under RCP2.6, RCP4.5 and RCP8.5, the projected snowmelt in China in 2030s (2050s, 2090s) may decrease by $13.4 \%$ $(16.3 \%, 13.8 \%), 19.1 \%(19.8 \%, 22.5 \%), 17.1 \%(24.7 \%, 42.8 \%)$ compared with the historical period (1951-2017),

25 respectively. Most of the projected mean annual snowmelt runoff ratios in third-level basins in different decades (2030s, 2050s and 2090s) were lower than those in the historical period. Low temperature regions can tolerate more warming, and the snowmelt change in these regions is mainly influenced by precipitation; however, the snowmelt change in warm regions is more sensitive to temperature increases. The spatial variability of snowmelt changes may lead to regional differences in the impact of snowmelt on water supply. 


\section{Introduction}

Snow properties have changed significantly under the ongoing warming of the global climate, and variations in snow cover exert strong feedbacks on the climate system due to its high albedo and low thermal conductivity as well as the high latent heat of phase change (Zhang and Ma, 2018; Pulliainen et al., 2020; Vano, 2020; You et al., 2020). Additionally, snow is a critical component of the hydrological system and water cycle, and snowmelt is a major fresh water resource in many regions (Mankin et al., 2015). More than one-sixth of the earth's population relies on snowmelt for their water supply, and snowmelt-dominated regions contributes roughly one-quarter of the global gross domestic product (Barnett et al., 2005). Climate warming has resulted in smaller snowfall/precipitation ratios, earlier snowmelt times and slower snowmelt rates (Berghuijs et al., 2014; Musselman et al., 2017; Barnhart et al., 2020). This has not only changed seasonal runoff distributions, but has also affected the total annual runoff (Bloschl et al., 2019; Jenicek and Ledvinka, 2020). Consequently, determining the amount of snowmelt and its variability under climate change is important for the planning and management of water resources, such as agricultural water management, flood forecasting, reservoir operation, and the design of hydraulic structures (Barnhart et al., 2020; Qin et al., 2020).

45 There are many models for calculating snowmelt, and these can be basically divided into two types: physically based snowmelt models and simpler temperature index models (also known as degree-day methods) (Skaugen et al., 2018; Li et al., 2019). In theory, physically based snowmelt models can provide more accurate predictions by considering the coupled interaction between energy components in complex snowmelt processes ( $\mathrm{Li}$ et al., 2019). However, many studies have shown that due to the mathematical complexities and massive data requirements of physically based models, they do not 50 necessarily perform better than temperature index models (Hock, 2003; Jost et al., 2012; Skaugen et al., 2018; Lopez et al., 2020). Temperature index models are based on the assumptions that the temporal variability of incoming solar radiation is adequately represented by the variations of air temperature that the snowmelt during a time interval is proportional to positive air temperatures (Hock, 2003; Jost et al., 2012; Lopez et al., 2020). Because of the wide availability of air temperature data, their computational simplicity, and their generally good model performance, temperature index models are

55 the most common approach for calculating snowmelt around the world (Hock, 2003; Immerzeel et al., 2010; Lopez et al., 2020).

China covers a vast area and a variety of climate regions, and its snow covered regions are widely distributed geographically with evident spatial differences (Tan et al., 2019). Northern Xinjiang, Northeast China-Inner Mongolia (hereafter referred to as the Northeast China) and the Tibetan Plateau are the three main regions with stable snow cover in China (Ke et al., 2016)

60 (Fig. 1a). As a typical arid and semi-arid region of Central Asia with a significant lack of freshwater resources, the surface runoff in the Xinjiang Uygur Autonomous Region (hereafter, Xinjiang) is mainly supplied by snow meltwater (Chen et al., 2020; Wu et al., 2021). In Northeast China, snow plays an important role as a natural reservoir in winter and a source of water in spring, with snowmelt contributing more than half of the runoff during the main crop planting months (April and May) (Qi et al., 2020). Snow melting is aslo an important hydrological process in the Tibetan Plateau, which is the source 
65 region of many major Asian rivers and considered as the asian water towers (Immerzeel et al., 2010). Snowmelt is also an important water source in other parts of China, especially the arid and semi-arid areas in North China (Zhang et al., 2015; Wu et al., 2021). Spatiotemporal changes in China's snow properties (e.g. snow cover extent, snow cover phenology, snow depth, snow density and snow water equivalent) have drawn wide attention in recent decades (Dai and Chen, 2010; Wang and Li, 2012; Chen et al., 2016; Ke et al., 2016; Tan et al., 2019; Ma et al., 2020; Yang et al., 2020); however, country-wide assessments of snowmelt are lacking. Projected increases in air temperature and associated precipitation regime shifts are expected to have significant consequences for snowmelt and water resources (Ficklin et al., 2016). Although many studies have investigated snowmelt in single or multiple basins (e.g. Zhang et al., 2015; Chen et al., 2019; Li et al., 2019; Zhang et al., 2020; Li et al., 2021), the spatiotemporal variability of snowmelt in China and its response to climate warming remain unclear.

75 Under this background, we developed a simple monthly temperature-index model to calculate the snowmelt in China using a high spatial resolution $(0.5$ seconds, approximately $1 \mathrm{~km})$ dataset of monthly air temperatures and precipitation. The model considered complex snow processes such as melting, accumulation and sublimation, and was validated using snowfall, snow depth, snow cover extent and snow water equivalent. The objectives of this study were to (1) quantify the snowmelt across China and in its three main stable snow cover distribution regions; (2) analyse the spatiotemporal variability of snowmelt in

80 China in the 1951-2017 period; (3) elucidate the spatiotemporal variability of snowmelt runoff ratio in third-level basins in China; (4) assess the impacts of projected future climate change on snowmelt in China.

\section{Study region and data sets}

\subsection{Study region}

In general, China can be divided into five main climatic zones: the mountain plateau zone (MPZ), the temperate monsoon zone (TMZ), the temperate continental zone (TCZ), the subtropical monsoon zone (SMZ) and the tropical monsoon zone (Yang et al., 2021) (Fig. 1b). Because the land area of the tropical monsoon zone is significantly smaller than that of the other climatic zones and it has extremely low snowfall, it was incorporated into the SMZ for parameter assignment. Additionally, because of the lack of meteorological data and the fact that it has very little snowfall, Taiwan was not considered in this study. The snow cover types in China can be divided into five types: prairie, taiga, tundra, mountain and ephemeral types (Li et al., 2020) (Fig. 1c). 

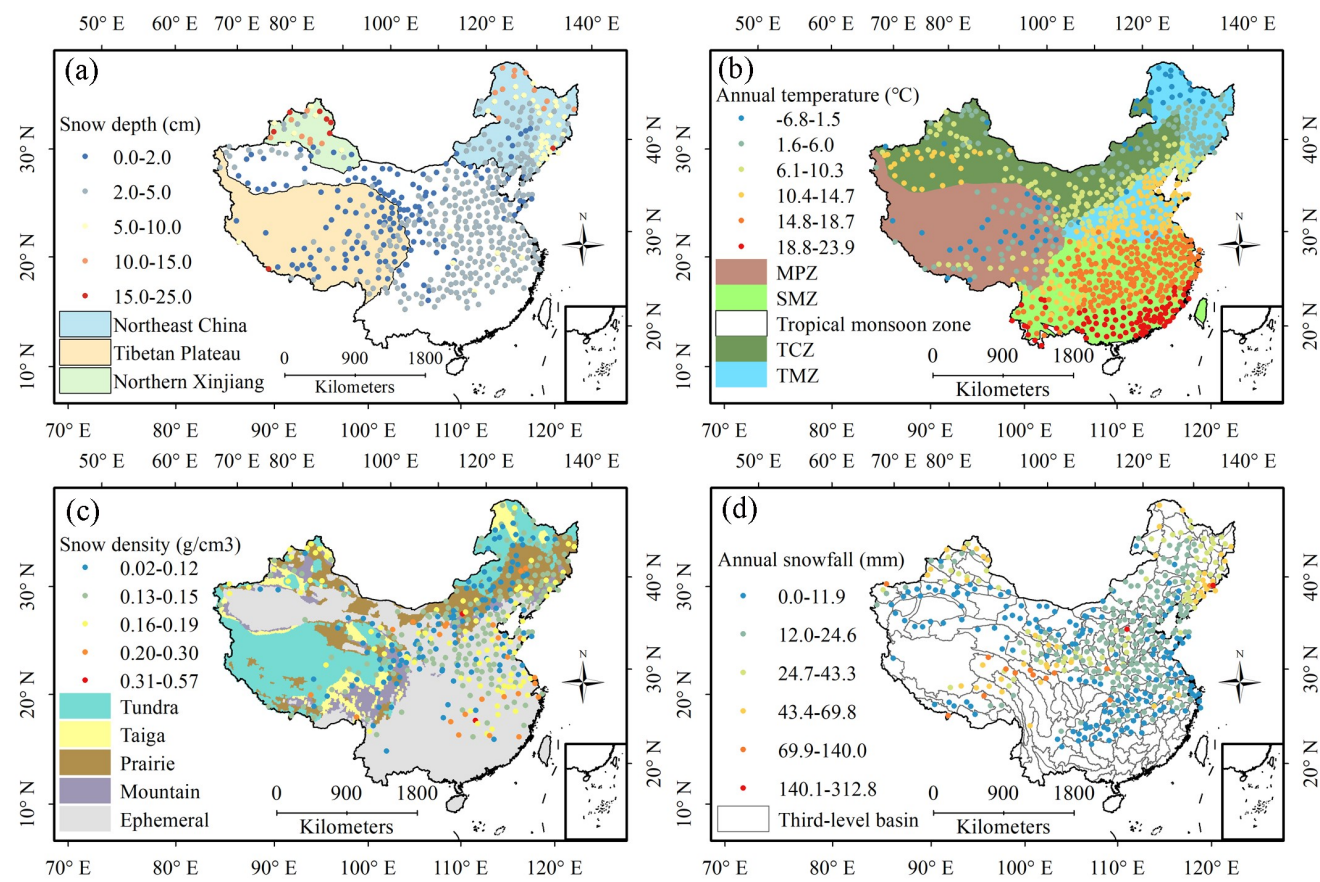

Figure 1. The three main stable snow cover regions and the mean snow depth in China (1951-2009) (a); China's five climatic zones (MPZ, mountain plateau zone; TMZ, temperate monsoon zone; TCZ, temperate continental zone; SMZ, subtropical monsoon 95 zone) and mean annual air temperature (1951-2017) (b); the snow cover classification and mean snow density in China (1999-2008) (c); the third-level basins and mean annual snowfall in China (1961-1979) (d).

\subsection{Data collection}

\subsubsection{High spatial resolution dataset of monthly air temperatures and precipitation}

Data with a high spatial resolution of 0.5 seconds (approximately $1 \mathrm{~km}$ ), including the monthly minimum, maximum, and

100 mean temperatures $\left(T_{\min }, T_{\max }\right.$, and $T_{a}$, respectively) and precipitation, were obtained from the Network Common Data Form (NetCDF)(https://doi.org/10.5281/zenodo.3114194 for precipitation; https://doi.org/10.5281/zenodo.3185722 for air temperatures). The data were spatially downscaled from the 30 seconds Climatic Research Unit time series data with the climatology dataset of WorldClim using delta spatial downscaling, and the data set was evaluated using observations collected from 1951 to 2016 by 496 meteorological stations across China. Detailed information on the dataset was given by Peng et al. (2019). Although the original data set covers the 1901 to 2017 period, we selected 1951 to 2017 as the study period, as only data from after 1951 have been validated by observations from meteorological stations. 


\subsubsection{Data sets for model parameterization}

The observational air temperature data used to determine positive degree-day $(P D D)$ parameters were collected from 824 meteorological stations (Fig. 1b) in the 1951-2017 period and were provided by the China Meteorological Administration (http://data.cma.cn/). The positive degree-day is defined as the cumulative temperature above $0^{\circ} \mathrm{C}$ over a given period (Wake and Marshall, 2017), and in this study, it was the monthly positive accumulated temperature.

The observational snow density data used to determine degree-day factors $(D D F)$ were collected from 417 meteorological stations in China (Fig. 1c) during 1999-2008 period and were provided by the China Meteorological Administration.

The threshold temperature parameters for determining the precipitation types at meteorological stations were obtained from Han et al. (2010), who derived threshold temperature parameters using air temperature and precipitation data from 643 meteorological stations in China from 1961 to 1979 (precipitation types are not labelled from 1980). The threshold temperatures of each calculated cell were interpolated using the parameters from the meteorological stations.

\subsubsection{Data sets for model evaluation}

The observational snowfall data used to validate the model were collected from 475 meteorological stations in China (Fig. 1d) during the 1961-1979 period and were provided by the China Meteorological Administration.

The observational snow depth data used to validate the model were collected from 557 meteorological stations in China (Fig. 1a) during the 1951-2009 period and were provided by the China Meteorological Administration.

A long time series of daily snow depth derived from passive microwave remote sensing data (1979-2018) was obtained from by the National Tibetan Plateau Data Center (http://data.tpdc.ac.cn). The data set covers the entire land surface of China with a spatial resolution of 0.25 degree. Detailed information on the dataset sources and product processes can be found in Che et al. (2008) and Dai et al. (2012). This data set has been widely utilized in climatic and hydrological research in China (e.g. Liu et al., 2020; Wu et al., 2021; Zhu et al., 2021). The spatial resolution of this dataset is significantly different from that of the air temperature and precipitation data used in this study. The snow cover extent measures generated from this dataset was used to validate the model.

130 Additionally, a long time series of daily snow water equivalent dataset derived from passive microwave remote sensing data (1980-2020) was provided by the National Cryosphere Desert Data Center (https://www.ncdc.ac.cn). The snow water equivalent dataset was produced from the passive microwave remote sensing data using the mixed-pixel method. The dataset covers the entire land surface of China with a spatial resolution of $25 \mathrm{~km}$. Detailed information on the dataset sources and product processes are given by Jiang et al. (2014) and Yang et al. (2019).

\subsubsection{Climate projections and downscaling}

Five CIMP5 models under three different representative concentration pathways scenarios (RCP2.6, RCP4.5 and RCP8.5), namely GFDL-ESM2M, HadGEM2-ES, IPSL-CM5A-LR, MIROC-ESM-CHEM, and NorESM1-M, were selected to predict 
the future snowmelt changes in China. Aforementioned climate projections have been bias-corrected downscaled to a grid with a resolution of 0.5 degrees (Hempel et al., 2013). The delta method was a statistically downscaled method corrected not only against the average observed climate but also for the observed variance, and was used to determine the monthly future meteorological data (2006-2099) based on the high-spatial-resolution temperature and precipitation dataset and the simulations of the five CIMP5 models during the historical period (1951-2005). Detailed information on the delta method was given in Immerzeel et al. (2012) and Zhao et al. (2019).

\section{Method}

\subsection{Snowmelt model}

Temperature index models are based on an assumed relationship between snowmelt and air temperature, which is usually expressed in the form of positive temperature sums. In this study, the snowmelt was calculated as follows:

$M_{m}=\min \left(D D F_{m} \cdot P D D_{m} \cdot D_{m}, S_{a c c, m}\right)$

$S_{\text {acc, } m}=S_{\text {acc, } m-1}+P_{\text {snow }, m}-S_{\text {sub }, m}-M_{m}$

150 where $M, S_{a c c}, P_{\text {snow }}$ and $S_{\text {sub }}$ are the snowmelt, snow accumulation, snowfall and snow sublimation (mm), respectively. $D D F$ is the degree-day factor $\left(\mathrm{mm}^{\circ} \mathrm{C}^{-1} \mathrm{day}^{-1}\right)$, an empirical factor that relates the rate of snowmelt to air temperature. $P D D$ is the accumulated positive air temperature $\left({ }^{\circ} \mathrm{C}\right)$. The subscript $m$ indicates the month, and $D$ is the number of days in the month $m$.

\subsubsection{Snowfall}

The determination of the precipitation types is the first crucial step, and the distinction between rainfall and snowfall is based on the assumption that precipitation falls either as rain, as snow or as mix, depending on two threshold temperature parameters:

$P_{\text {snow }}=\left\{\begin{array}{cc}0 & T_{a} \geq T_{\text {rain }} \\ P \cdot\left(T_{\text {rain }}-T_{a}\right) /\left(T_{\text {rain }}-T_{\text {snow }}\right) & T_{\text {snow }}<T_{a}<T_{\text {rain }} \\ P & T_{a} \leq T_{\text {snow }}\end{array}\right.$

where $P_{\text {snow }}$ and $P$ are the monthly snowfall and precipitation $(\mathrm{mm})$, respectively. $T_{a}$ is the monthly mean temperature $\left({ }^{\circ} \mathrm{C}\right)$. $T_{\text {rain }}$ and $T_{\text {snow }}$ are the threshold temperature $\left({ }^{\circ} \mathrm{C}\right)$ for rainfall and snowfall, respectively.

\subsubsection{DDF}

$D D F$ is the key parameter of the temperature index snowmelt model, which depends on the snow density and varies with space and time. We used the following the empirical equation to determine the $D D F$ after Rajkumari et al. (2019):

$D D F=1.1\left(\rho_{s} / \rho_{w}\right)$

where $\rho_{s}$ and $\rho_{w}$ are the density of snow and water $\left(\mathrm{g} \mathrm{cm}^{-3}\right)$, respectively, and $D D F$ is the degree-day factor $\left(\mathrm{cm}^{\circ} \mathrm{C}^{-1} \mathrm{day}^{-}\right.$

$\left.{ }^{1}\right)$. For taiga regions (Fig. 1c), the equation was corrected as follows: 
The $D D F$ values at the meteorological stations were calculated for each month, and were then interpolated to each calculated cell.

\subsubsection{PDD}

170 Based on the daily mean air temperatures from 1960 to 2018 at meteorological stations in China, Liu et al. (2021) proposed a simple method to calculate the monthly $P D D$ according to the monthly mean temperature:

$P D D=\left\{\begin{array}{cc}0 & T_{a} \leq T_{1} \\ a \cdot T_{a}^{2}+b \cdot T_{a}+c & T_{1}<T_{a}<T_{2} \\ T_{a} \cdot D_{m} & T_{a} \geq T_{2}\end{array}\right.$

where $T_{1}$ and $T_{2}$ are threshold temperatures $\left({ }^{\circ} \mathrm{C}\right) ; a, b$ and $c$ are empirical parameters.

First, $T_{1}, T_{2}, a, b$ and $c$ were calculated according to the measured data from meteorological stations in the four different climate zones (Fig. 1b), and were then interpolated to each calculated cell. Table 1 shows the different threshold temperatures and empirical parameters in the four climate zones, and Fig. 2, shows the relationship between the measured monthly $P D D$ and the mean temperature at meteorological stations, and the relationship between the calculated and measured monthly $P D D$, taking the MPZ as an example. Statistical analysis shows that the equation (6) can adequately calculate the monthly $P D D$ (Table 1).

180 Table 1. The parameters required for the calculation of the monthly accumulated positive air temperature (PDD) and the statistical analysis between the calculated and measured monthly $P D D$ in four different climatic zones of China.

\begin{tabular}{lllllllrrr}
\hline & \multicolumn{1}{l}{$T_{1}$} & \multicolumn{1}{l}{$T_{2}$} & \multicolumn{1}{l}{$a$} & \multicolumn{1}{l}{$b$} & \multicolumn{1}{l}{$c$} & \multicolumn{1}{l}{$R^{2}$} & MAE & \multicolumn{1}{l}{ RMSE } & \multicolumn{1}{l}{ NSE } \\
\hline MPZ & -7.99 & 5.79 & 0.79 & 15.37 & 56.38 & 1.00 & 5.87 & 10.85 & 1.00 \\
TCZ & -10.85 & 9.89 & 0.52 & 15.29 & 85.38 & 1.00 & 7.96 & 15.32 & 1.00 \\
TMZ & -10.41 & 9.51 & 0.52 & 15.45 & 81.43 & 1.00 & 8.45 & 16.56 & 1.00 \\
SMZ & -4.05 & 8.56 & 0.22 & 23.12 & 49.63 & 1.00 & 2.67 & 7.63 & 1.00
\end{tabular}

Note. MPZ, mountain plateau zone; TMZ, temperate monsoon zone; TCZ, temperate continental zone; SMZ, subtropical monsoon zone; $T_{1}, T_{2}, a, b$ and $c$, parameters in the Eq. 6); $R^{2}$, coefficient of determination; MAE, mean absolute error $\left({ }^{\circ} \mathrm{C}\right) ; \mathrm{RMSE}$, root mean square error $\left({ }^{\circ} \mathrm{C}\right) ; N S E$, Nash-Sutcliffe efficiency. 

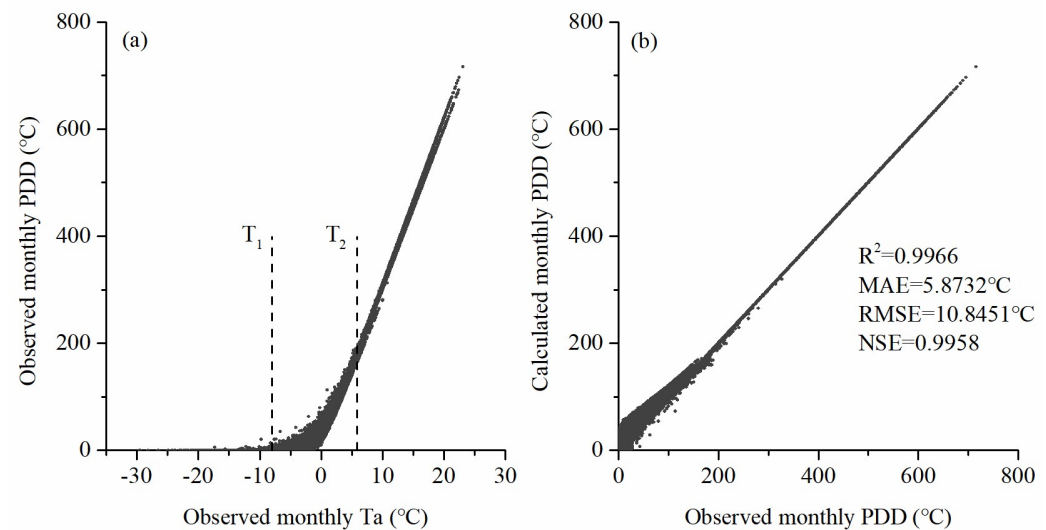

Figure 2. The relationship between the observed monthly accumulated positive air temperature (PDD) and mean air temperature ( $\left.T_{a}\right)$ (a), and the scatter plot between the calculated and observed monthly $P D D(b)$ at meteorological stations in the mountain plateau zone of China. $R^{2}$, coefficient of determination; $M A E$, mean absolute error $\left({ }^{\circ} \mathrm{C}\right) ; \mathrm{RMSE}$, root mean square error $\left({ }^{\circ} \mathrm{C}\right)$; $N S E$, Nash-Sutcliffe efficiency.

\subsubsection{Snow sublimation}

As a loss of water from the snowpack to the atmosphere, snow sublimation is difficult to quantify by measurement or modelling (Stigter et al., 2018). The bulk aerodynamic method and aerodynamic profile method are the common methods to calculate snow sublimation (Svoma, 2016). Some researchers used evapotranspiration equations (e.g. Penman-Monteith method) to estimate sublimation (Stigter et al., 2018). In general, these methods require accurate meteorological data and are very difficult to scale up from the microscale to the macroscale (Svoma, 2016). Many studies have reported the ratio of snow sublimation to snowfall (e.g. Zhang et al., 2008; Zhu et al., 2014; Sexstone et al., 2018). Therefore, considering the limited data availability and monthly scale of this study, the following simple equation was used to estimate the monthly snow sublimation.

$200 S_{\text {sub }}=\min \left(k \cdot S_{a c c}, P E T\right)$

where $k \cdot S_{a c c}$ and PET are the amount of snow accumulation available for sublimation and the potential sublimation (mm), respectively. The empirical parameter $k$ was set according to studies reporting the ratio of snow sublimation to snowfall in China and surrounding areas (Table S2 and Fig. S1), as shown in Table 2.

PET was calculated by the Hargreaves-Samani method (Hargreaves and Samani, 1985):

$205 P E T=0.0023 \cdot R_{a}\left(T_{a}+17.8\right)\left(T_{\max }-T_{\min }\right)^{0.5} / \lambda$

where $T_{a}, T_{\max }$ and $T_{\min }$ are the monthly average temperature, maximum temperature and minimum temperature $\left({ }^{\circ} \mathrm{C}\right)$, respectively; $R_{a}$, is the extraterrestrial radiation $\left(\mathrm{MJ} \mathrm{m}^{-2} \mathrm{month}^{-1}\right)$, which is a function of the latitude and the Julian day; $\lambda$ is the latent heat of vaporisation $\left(\mathrm{MJ} \mathrm{kg}^{-1}\right)$. 
210 Table 2. The values of the empirical parameter $k$ used to estimate snow sublimation (Eq. 7 ) for different climate zones and different snow types

\begin{tabular}{lllll}
\hline Snow cover type & MPZ & TCZ & TMZ & SMZ \\
\hline Tundra & 0.68 & 0.43 & 0.37 & - \\
Taiga & 0.63 & 0.42 & 0.33 & - \\
Prairie & 0.41 & 0.22 & 0.15 & - \\
Mountain & 0.55 & 0.35 & 0.31 & - \\
Ephemeral & 0.23 & 0.10 & 0.09 & 0.08
\end{tabular}

Note. MPZ, mountain plateau zone; TMZ, temperate monsoon zone; TCZ, temperate continental zone; SMZ, subtropical monsoon zone.

\subsection{Snowmelt runoff ratio}

215 The snowmelt runoff ratio, which represents the contribution of snowmelt to river discharge, is defined as the percentage of runoff derived from snowmelt to the total runoff. Hydrological models are generally effective for determining the snowmelt runoff ratio (Immerzeel et al., 2010; Jenicek and Ledvinka, 2020), however, they are difficult to implement over large regions due to data limitations and large computational requirements. Therefore, many studies have used indirect indicators to estimate the snowmelt runoff ratio, such as the ratios of total snowfall to total precipitation, total snowfall to total runoff,

220 or melt season runoff to total annual runoff ( $\mathrm{Li}$ et al., 2017). Snowmelt and rainfall are the sources of runoff generation (Vormoor et al., 2016). In this study, the snowmelt runoff ratio was calculated as the ratio of snowmelt to the sum of snowmelt and rainfall:

Snow $_{r}=M /\left(M+P_{\text {rain }}\right) \times 100$

where $M$ and $P_{\text {rain }}$ are the snowmelt and rainfall $(\mathrm{mm})$, respectively, and Snow $w_{r}$ is the percentage of runoff derived from snowmelt to the total runoff.

\subsection{Trend analysis}

The non-parametric Mann-Kendall test (Mann, 1945; Kendall, 1975) was used to analyse the trend and significance level of the snowmelt and other variables:

$Z=\left\{\begin{array}{cc}(S-1) / \sqrt{\operatorname{var}(S)} & S>0 \\ 0 & S=0 \\ (S+1) / \sqrt{\operatorname{var}(S)} & S<0\end{array}\right.$

$230 S=\sum_{k=1}^{n-1} \sum_{j=k+1}^{n} \operatorname{sgn}\left(x_{j}-x_{k}\right)$

$\operatorname{sgn}\left(x_{j}-x_{k}\right)=\left\{\begin{array}{cc}1 & \left(x_{j}-x_{k}\right)>0 \\ 0 & \left(x_{j}-x_{k}\right)=0 \\ -1 & \left(x_{j}-x_{k}\right)<0\end{array}\right.$

$\operatorname{var}(S)=\frac{n(n-1)(2 n+5)-\sum_{i=1}^{m} t_{i}\left(t_{i}-1\right)\left(2 t_{i}+5\right)}{18}$ 
where $n$ is the number of data set, $x_{j}$ and $x_{k}$ are the data values in time series $j$ and $k, m$ is the number of tied groups and $t_{i}$ denotes the number of ties of extent $i$. A tied group is a set of sample data having the same value. Positive and negative values of $Z$ indicate increasing and decreasing trends, respectively. Testing trends is done at the specific $\alpha$ significance level. If $|Z|>Z_{1-\alpha / 2}$, the trend is statistically significant; otherwise the trend is not statistically significant. In this study, significance levels of $\alpha=0.05$ ( $95 \%$ confidence level) were applied.

Additionally, Sen's slope method (Sen, 1968) was used to analyse the slope of the variation:

$\beta=\operatorname{median}\left(\frac{x_{j}-x_{k}}{j-k}\right), j>k$

240 where $\beta$ sign reflects data trend reflection, while its value indicates the steepness of the trend.

\subsection{Evaluation criteria}

Statistical indices were used for quantitative analysis of the snowmelt model performance, and a series of statistical criteria used in this study as follows:

$R^{2}=\left[\operatorname{cov}\left(X_{S}, X_{o}\right) / \sigma X_{S} \sigma X_{o}\right]^{2}$

$M A E=\frac{1}{n} \sum_{i=1}^{n}\left|X_{s i}-X_{o i}\right|$

$R M S E=\sqrt{\frac{\sum_{i=1}^{n}\left(X_{S i}-X_{o i}\right)^{2}}{n}}$

$N S E=1-\frac{\sum_{i=1}^{n}\left(X_{S i}-X_{o i}\right)^{2}}{\sum_{i=1}^{n}\left(X_{o i}-\overline{X_{O}}\right)^{2}}$

where $R^{2}, M A E, R M S E$ and NSE are the coefficient of determination, mean absolute error, root mean square error, and NashSutcliffe efficiency, respectively. $X_{s i}$ and $X_{o i}$ represent simulated and observed data at time $i$, respectively. $n$ is the number of data points, and cov and $\sigma$ are the covariance and standard deviation, respectively.

\section{Results}

\subsection{Model performance}

\subsubsection{Snowfall validation using observational data from meteorological stations}

Although observational snowfall data from 475 meteorological stations in China were collected, due to data scarcity or the very low snowfall at some stations, snowfall data from 457 stations were used to verify the snowfall from the model. Fig. 3 shows the statistical criteria between the calculated and observed snowfall at meteorological stations in China from 1961 to 1979. The MAE and RMSE varied greatly between stations due to the huge difference in the amount of snowfall at each station. The ratios of MAE and RMSE to monthly mean snowfall (MAE/Mean and RMSE/Mean, respectively) were selected to analyse the model performance. Of the 457 stations, 315 (68.9\%) had $R^{2}>0.4 ; 263$ (5.7\%) had MAE/Mean $<1 ; 274$ $(60.0 \%)$ had RMSE/Mean < 1, accounting for 60.0\%; and $296(64.7 \%)$ had NSE $>0.2$. Among China's three main stable 
snow cover regions, the most accurate snowfall simulation was obtained for Northeast China, followed by North Xinjiang and then the Tibetan Plateau.
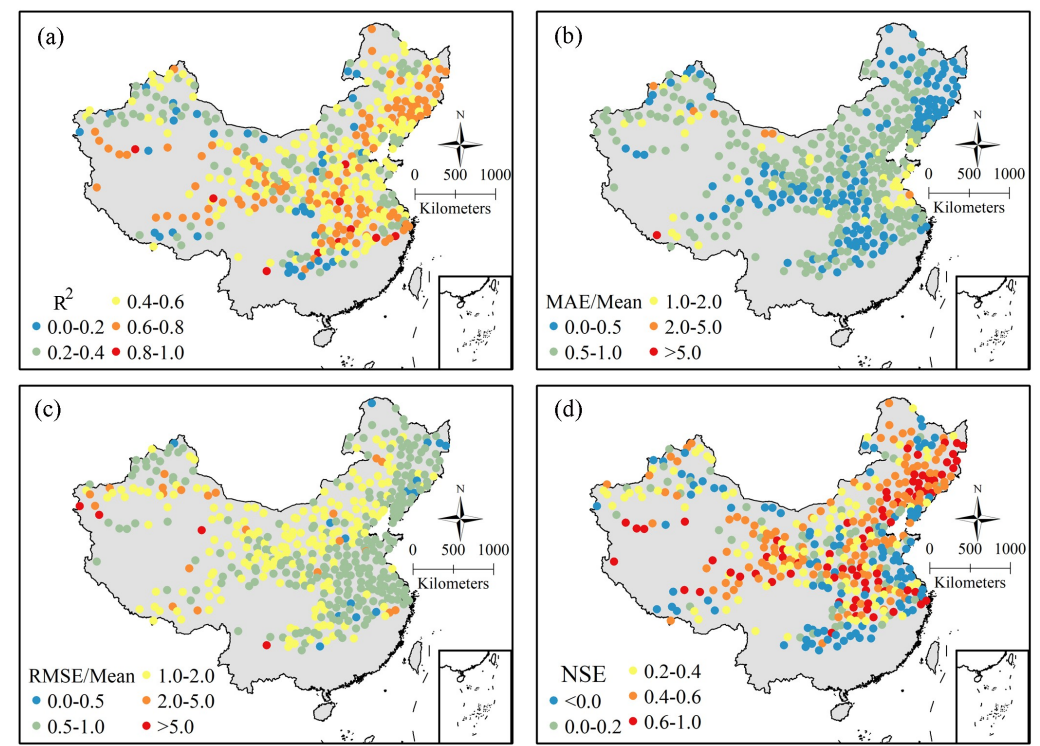

Figure 3. Statistical criteria of the calculated snowfall against observed snowfall at 457 meteorological stations in China (a, $R^{2}$, 265 coefficient of determination; b, MAE/Mean, MAE, mean absolute error; Mean, monthly mean snowfall; c, RMSE/Mean, RMSE, root mean square error; d, NSE, Nash-Sutcliffe efficiency).

\subsubsection{Snow depth validation using observational data from meteorological stations}

The monthly snow depth in each grid was calculated from the snow accumulation and snow density. As the snow depth was observed at meteorological stations daily, the snow depth observation on the last day of each month was selected to verify the model's snow depth output. Because of the scarce data or the very shallow snow at some stations, the snow depth observations from only 264 stations were selected to verify the snow depth from the model. Fig. 4 shows the statistical analyses of the calculated and observed snow depths in China from 1951 to 2009. Similar to snowfall validation, besides $R^{2}$ and NSE, the ratio of MAE and RMSE to the mean snow depth (MAE/Mean and RMSE/Mean, respectively) were selected to analyse the model performance. Of the 264 stations, 108 (40.9\%) had $R^{2}>0.2 ; 221$ (83.7\%) had MAE/Mean $<2 ; 52(19.7 \%)$ had $R M S E /$ Mean $<2$; and $105(39.8 \%)$ had $N S E>0$. Better snow depth simulations were obtained in regions with larger snow depths, such as Northeast China and North Xinjiang. 

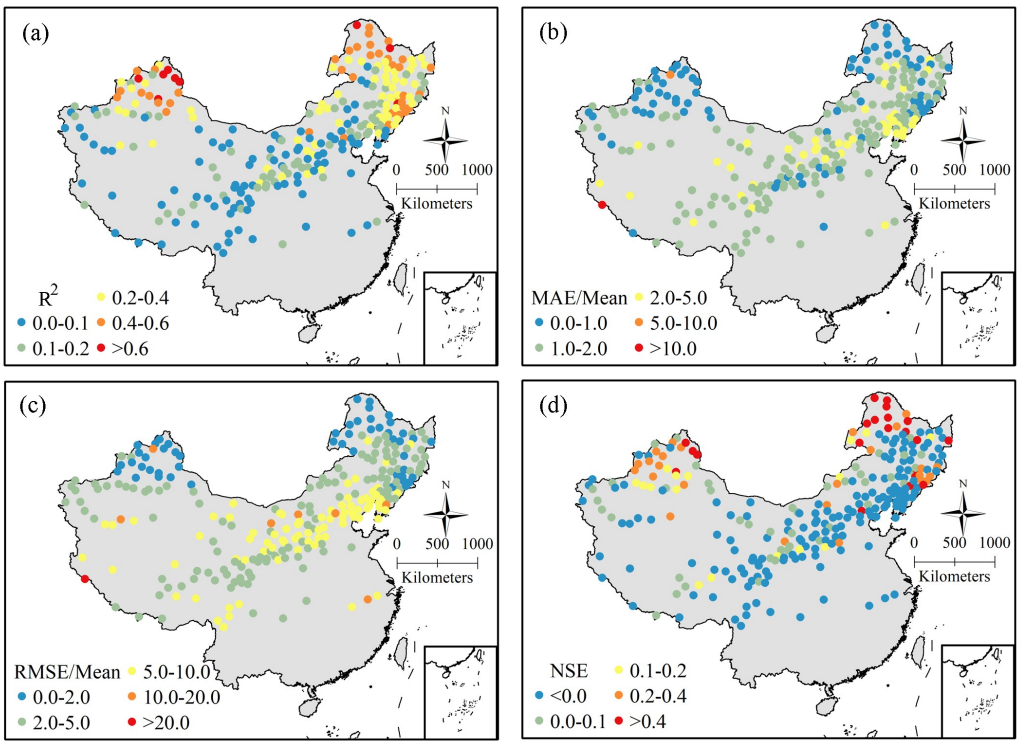

Figure 4. Statistical criteria of the calculated snow depth against observed snow depth at 264 meteorological stations in China (a, $R^{2}$, coefficient of determination; $\mathrm{b}, M A E / M e a n, M A E$, mean absolute error; Mean, mean snow depth; c, RMSE/Mean, RMSE, root mean square error; d, NSE, Nash-Sutcliffe efficiency).

\subsubsection{Snow cover extent validation using the dataset derived from passive microwave remote sensing}

As the extend of the snow cover derived from remote sensing has a daily time scale and the snowmelt model has a monthly time scale, the remote sensing data on the last day of each month were selected to verify the model's snow cover extent output. The $R^{2}, M A E, R M S E$ and NSE between the snow cover extent output by the model against dataset derived from remote sensing in China from 1979 to 2017 , were $0.93,0.45 \times 10^{6} \mathrm{~km}^{2}, 0.64 \times 10^{6} \mathrm{~km}^{2}$ and 0.89 , respectively. Among the three main stable snow cover regions, the $R^{2}, M A E, R M S E$ and NSE were, respectively $0.81,0.06 \times 10^{6} \mathrm{~km}^{2}, 0.09 \times 10^{6} \mathrm{~km}^{2}$ and 0.76 , for Northern Xinjiang, $0.93,0.13 \times 10^{6} \mathrm{~km}^{2}, 0.21 \times 10^{6} \mathrm{~km}^{2}$ and 0.87 for Northeast China, and $0.90,0.32 \times 10^{6} \mathrm{~km}^{2}, 0.40 \times 10^{6}$ $\mathrm{km}^{2}$ and 0.81 for the Tibetan Plateau (Fig. 5). 


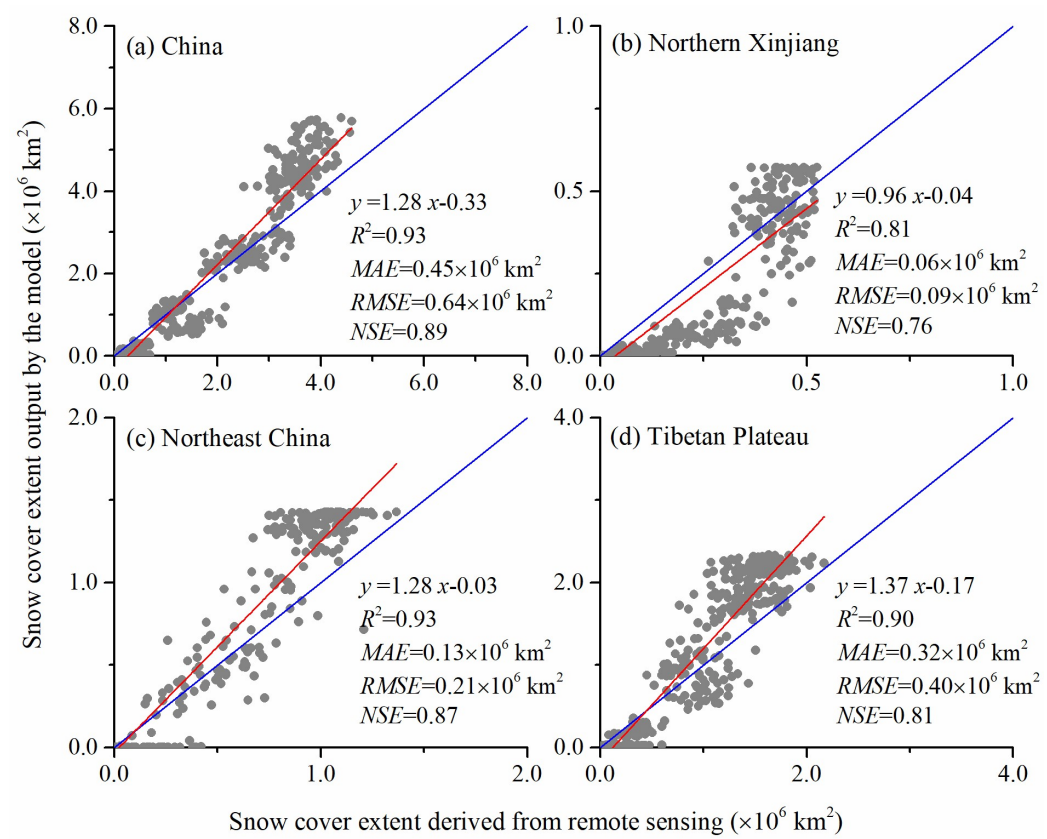

Figure 5. Scatterplots of the snow cover extent output by the model and derived from remote sensing in China and its three main stable snow cover regions. The red and blue solid lines are the linear fit and the 1:1 line, respectively.

\subsubsection{Snow water equivalent validation using the dataset derived from passive microwave remote sensing}

The snow water equivalent derived from passive microwave remote sensing on the last day of each month was used to verify the snow accumulation output by the model. As the spatial resolution of the snow water equivalent dataset was $25 \mathrm{~km}$, and the grid scale of the model was about $1 \mathrm{~km}$, to facilitate comparison, they were uniformly converted into water equivalent units of $\mathrm{m}^{3}$ for different regions. The $R^{2}, M A E, R M S E$ and NSE between the snow accumulation output by the model against snow water equivalent dataset in China from 1980 to 2017 , were $0.62,1.27 \times 10^{10} \mathrm{~m}^{3}, 1.27 \times 10^{10} \mathrm{~m}^{3}$ and 0.80 , respectively. The $R^{2}, M A E, R M S E$ and NSE for the three main stable snow cover regions are shown in Fig. 6. A large number of glaciers are distributed in the Tibetan Plateau, many of which may not be recorded in the remote sensing-based snow water equivalent dataset because its spatial resolution of about $25 \mathrm{~km}$ is larger than the width of most glaciers. This can explain the fact that a snow water equivalent of 0 is observed in some months in this region. However, the spatial scale of the model is about $1 \mathrm{~km}$, meaning that the snow accumulation in the glacier areas is always detected. This can explain the observation that in the Tibetan Plateau the modelled snow water equivalent is higher than the remote sensing-based values. When the snow accumulation in the glacier areas was not considered, the model performance improved in both the Tibetan Plateau and the whole of China (MAE and RMSE decreased and NSE increased; see Fig. S2). 

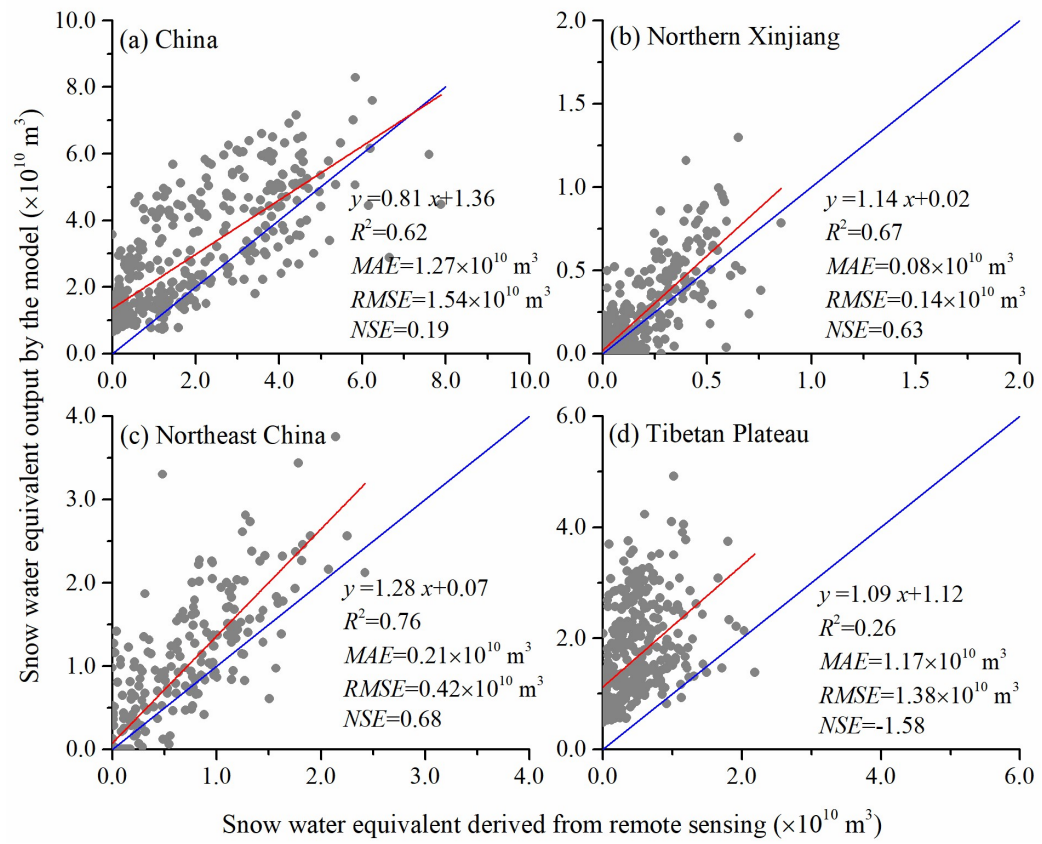

Figure 6. Scatterplots of the snow water equivalent output by the model and derived from remote sensing in China and its three main stable snow cover regions. The red and blue solid lines are the linear fit and the 1:1 line, respectively.

\subsection{Spatial and temporal variability of snowmelt}

\subsubsection{Spatial distribution}

The mean annual snowmelt in China from 1951 to 2017 was about $2.41 \times 10^{11} \mathrm{~m}^{3}$. The three main stable snow cover regions accounted for about $72.62 \%$ of the total snowmelt in China, with the mean annual snowmelt in Northern Xinjiang, Northeast China and Tibetan Plateau being about $0.18 \times 10^{11} \mathrm{~m}^{3}, 0.42 \times 10^{11} \mathrm{~m}^{3}$ and $1.15 \times 10^{11} \mathrm{~m}^{3}$, respectively. Southeast China (mainly

315 the Huaihe River basin and the lower reaches of the Yangtze River) also had high snowmelt due to heavy snowfall (Fig. 7a) The areas with with the lowest snowmelt were mainly distributed in the arid region of Northwest China, because of this region's low precipitation, and in the humid region of South China, because of this region's high air temperature and low snowfall.

The spatial pattern of snowmelt differed considerably during the year (Fig. 8). In the three stable snow cover regions, in winter, the air temperature was low and there was little snowmelt. The winter snowmelt mainly occurred in South China. In spring, North Xinjiang and Northeast China were the main regions of snowmelt in China. With further warming, the Tibetan 
Plateau became the main region of snowmelt until May. In summer, there was no snowfall in most of China and snowmelt occurred only in the high mountains of the Tibetan Plateau and the Tianshan Mountains.
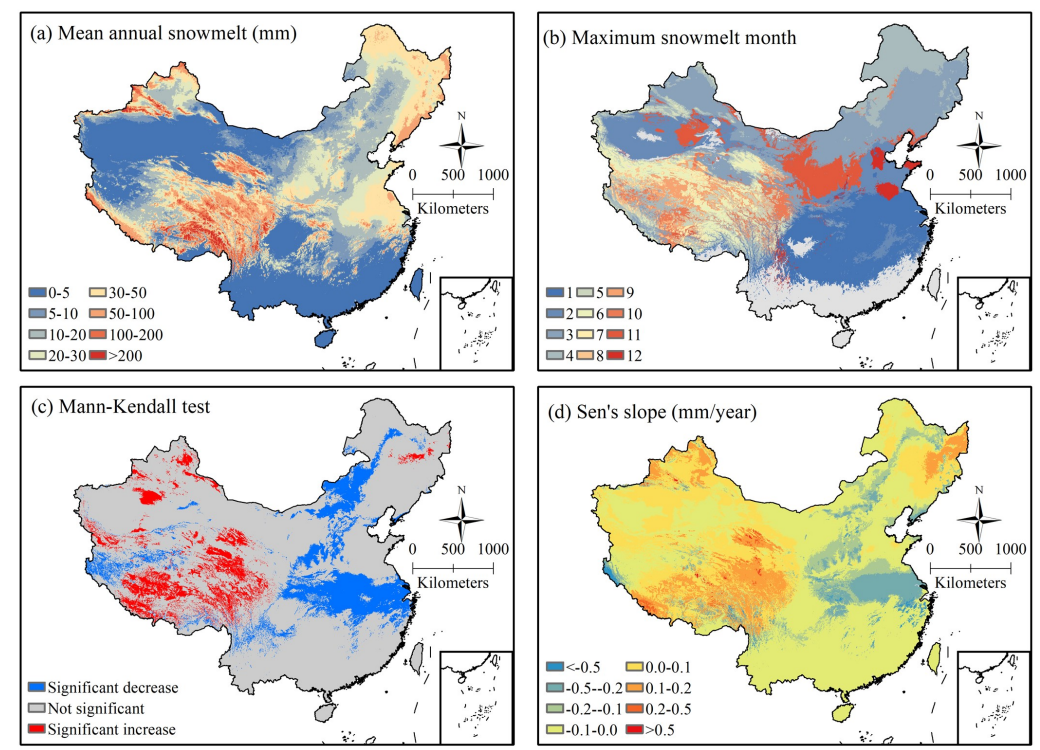

Figure 7. Spatial distribution of mean annual snowmelt (a), the month of maximum snowmelt (b); trends of annual snowmelt based on the Mann-Kendall method (c); Sen's slope of the annual snowmelt in China during the 1951-2017 period.

The month of maximum snowmelt differed between regions (Fig. 7b). In the Northern Xinjiang and Northeast China, due to the warming in spring, the maximum monthly snowmelt generally occurred in March, April or May. Meanwhile, in North and Southeast China, which are ephemeral snow regions where the snow melts quickly after falling, the maximum snowmelt generally occurred in the month with the largest snowfall (which occurred in winter). Because of the Tibetan Plateau's complex terrain and varied climate, the months of maximum snowmelt varied greatly across this region. In the southeastern part of the Tibetan Plateau, the month of maximum snowmelt occurred during the winter snowfall period because of the warm and humid climate. In the Gangdise Mountains, the Caidamu Basin and other colder regions, the month of maximum snowmelt generally occurred in spring. Meanwhile, in the Qiangtang Plateau, which has a drier climate, most snowfall occurred in summer, and the month of maximum snowmelt also occurred in this season. There were many high elevations mountains in the Tibetan Plateau, with air temperatures above $0{ }^{\circ} \mathrm{C}$ for only a few days in the summer, and the month of maximum snowmelt in those high elevations areas also occurred in summer. 

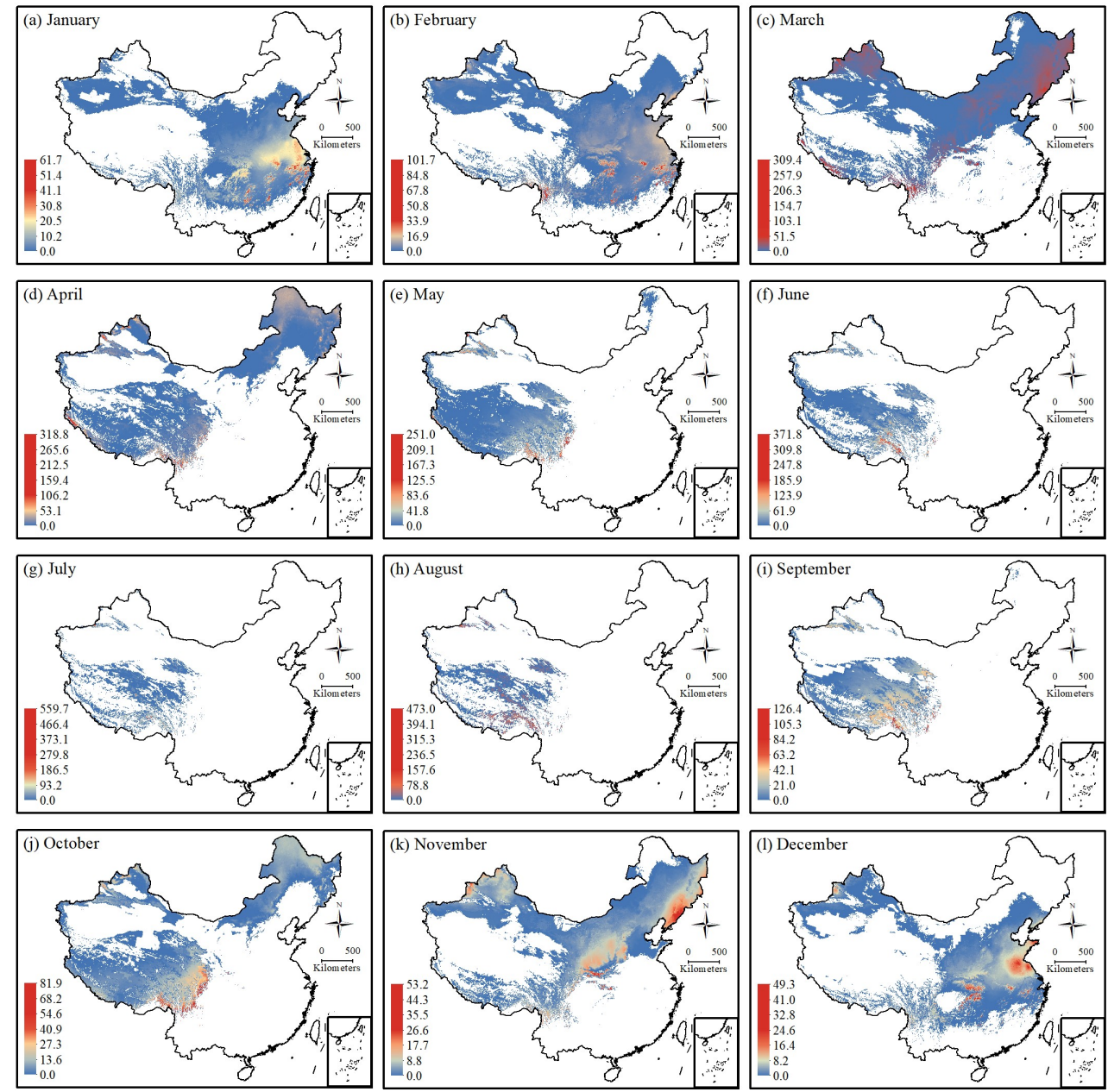

Figure 8. Spatial distribution of the mean monthly snowmelt $(\mathrm{mm})$ in 12 months in China during the 1951-2017 period.

\subsubsection{Temporal variations}

From 1951 to 2017, the annual snowmelt increased significantly in some areas of Northern Xinjiang, although it did not increase significantly in Northern Xinjiang as a whole. In Northeast China, although the central and eastern regions showed a significant increasing trend, the southwestern regions showed a decreasing trend, leading to a slight decreasing trend (although not a significant trend) in the whole of Northeast China. Annual snowmelt increased significantly in most parts of 
the Tibetan Plateau, leading to a significant increasing trend in the Tibetan Plateau as a whole. Southeast China, the annual snowfall decreased due to climate warming, and snowmelt also decreased significantly in this region, leading to a decreasing trend (although not a significant trend) of annual snowmelt in China (Fig. 7c, Fig. 7d and Fig. 9). From 1951 to 2017, the linear trends of annual snowmelt in China, Northern Xinjiang, Northeast China, and Tibetan Plateau were $-2.7 \times 10^{9}$ $\mathrm{m}^{3}$ decade $^{-1}, 0.2 \times 10^{9} \mathrm{~m}^{3}$ decade $^{-1},-0.3 \times 10^{9} \mathrm{~m}^{3}$ decade $^{-1}$ and $1.4 \times 10^{9} \mathrm{~m}^{3}$ decade ${ }^{-1}$, respectively.

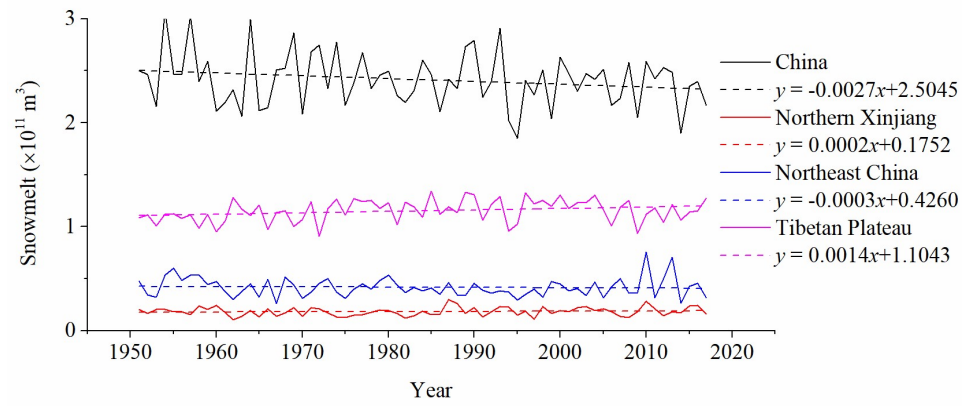

Figure 9. Interannual variability of the mean annual snowmelt in China and its three main stable snow cover regions from 1951 to 2017.

The temporal trend of snowmelt in each month from 1951 to 2017 varied across China (Fig. S3, Fig. S4). In Northern Xinjiang and Northeast China, snowmelt increased significantly in March, while decreased significantly in April. This implied that the warming of these two regions led to the earlier snowmelt time. Regarding seasonal changes between 1951 and 2017, in the Tibetan Plateau, spring snowmelt increased significantly, whereas summer snowmelt decreased significantly. This may be due to the warming in spring and the reduction of snowfall in summer. In Southeast China, snowmelt experienced a decreasing trend in almost all months because of the reduction in snowfall due to climate warming.

\subsection{Spatial and temporal variability of the snowmelt runoff ratio}

\subsubsection{Spatial distribution}

Of the 210 third-level basins in China, only nine small basins near the tropical monsoon region had no snowmelt runoff from 1951 to 2017 (as snowmelt was not calculated in Taiwan, it was assumed that there was no snowmelt there). In West China, which contains two main stable snow cover region - Northern Xinjiang and the Tibetan Plateau - the mean annual snowmelt runoff ratios were more than $10 \%$ in all basins, except those in the the Taklimakan Desert. In the basins in North and Northeast China, the snowmelt runoff ratios were generally more than $5 \%$, whereas, due to heavy rainfall, the snowmelt runoff ratios in basins in South China were generally less than $2 \%$ (Fig. 10a).

The monthly snowmelt runoff ratio also showed large spatial differences (Fig. 11). In the cold months of November, December, January, and February, the snowmelt runoff ratios in the basins of Central and North China were over $30 \%$ due to the precipitation being dominated by snowfall. Because of the extremely low temperatures in cold months, and there was no 
snowmelt or rainfall in some basins of the three stable snow cover regions. In March, although the rainfall increased, the snowmelt from the snow that accumulated in winter also increased, and the snowmelt runoff ratios were still relatively high in most basins of North China. In April, the snowmelt runoff ratios began to decline in most basins, and basins with snowmelt runoff ratios greater than $30 \%$ were mainly located in the three stable snow cover regions. In May and June, the snowmelt runoff ratios further decreased, dropping to zero in most of South, East, and Northeast China; however, they were still more than $30 \%$ in some basins in Northern Xinjiang and the Tibetan Plateau. In July and August, there was no snowmelt runoff in any basins except for some in Xinjiang and the Tibetan Plateau, and almost no basins had a snowmelt runoff ratio of more than 30\%. In September and October, snowfall and snowmelt gradually increased, leading to a gradual increase in the snowmelt runoff ratio in many basins.
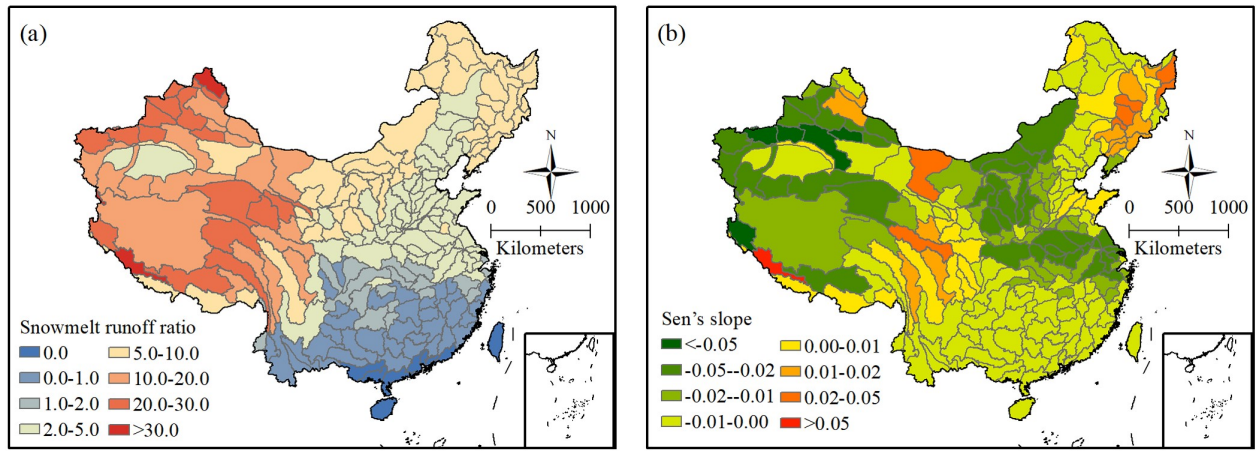

Figure 10. Spatial distribution of the mean annual snowmelt runoff ratio (\%) (a), and Sen's slope of the annual snowmelt runoff ratio $\left(\%\right.$ year $\left.{ }^{-1}\right)(b)$ in third-level basins in China during the 1951-2017 period. 

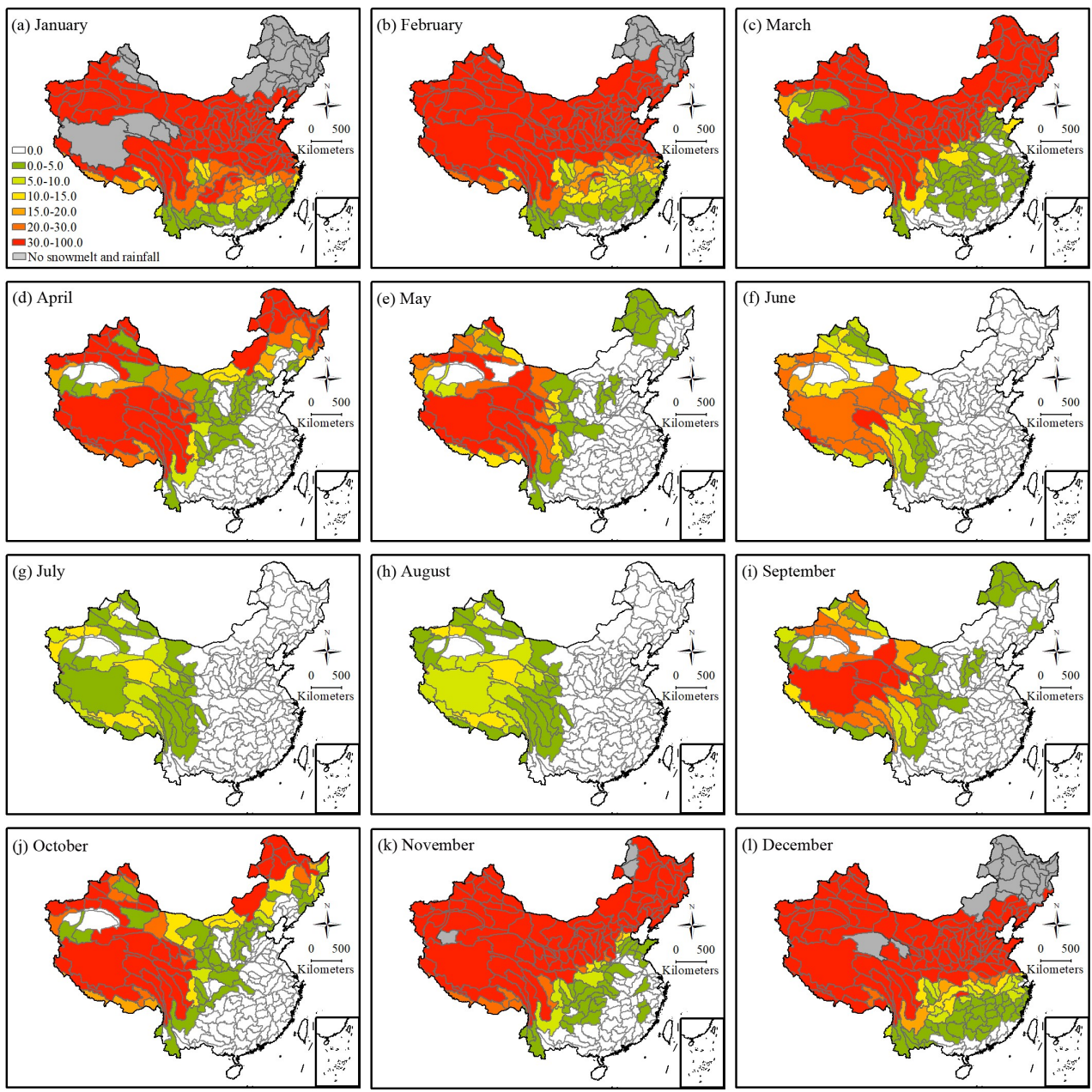

Figure 11. Spatial distribution of the monthly mean snowmelt runoff ratio (\%) in 12 months in third-level basins in China during the 1951-2017 period.

\subsubsection{Temporal variations}

From 1951 to 2017, the Sen's slope in third-level basins showed that the annual snowmelt runoff ratio decreased in most basins (Fig. 10b). Additionally, the Mann-Kendall test showed the basins with a significant decreasing trend of the snowmelt runoff ratio were mainly distributed in central Inner Mongolia, the southern slope of the Tianshan Mountains and South China (Fig. S5). The basins with an increased snowmelt runoff ratio were mainly distributed in the southeastern the Tibetan 
Plateau, the Heihe River basin in the Qilian Mountains, the Gurbantunggut Desert and Wulungu River in Northern Xinjiang, and the Songhua River basin in Northeast China. Among these basins, the Mann-Kendall test showed that only 4 basins had significant increasing trends: the source region of the Yellow River and three sub-basins of the Songhua River.

The temporal trend in the snowmelt runoff ratio from 1951 to 2017 showed spatial variations in China in every month (Fig. S6, Fig. S7). In the third-level basins in Central and East China, the snowmelt runoff ratio decreased in almost every month. In December, January and February, the snowmelt runoff ratio decreased significantly in the sub-basins of the Huaihe River and the middle and lower reaches of the Yangtze River. In March, the snowmelt runoff ratio decreased mainly in the middle reaches of the Yellow River and in the Northwest China. In April and May, the snowmelt runoff ratios decreased significantly in Northern Xinjiang and Northeast China, and in June, July and August, they decreased significantly in the Tibetan Plateau, Tianshan Mountains and Altai Mountains. In September, the snowmelt runoff ratios decreased in only a few basins, mainly in the Tianshan Mountain and the edge of the Tibetan Plateau. In October, the snowmelt runoff ratios decreased significantly mainly in Northern Xinjiang and central Inner Mongolia in October, and in November, they decreased significantly in Southern Xinjiang and the middle reaches of the Yellow River. In some months, the snowmelt runoff ratio increased in a few basins, mainly in the Tibetan Plateau and nearby areas. For example, in May, the snowmelt runoff ratios showed a large increase in the upper reaches of four rivers: the Yangtze River, the Nu River, the Lancang River, and the Yarlung Zangbo River; however, the Mann-Kendall test showed that few of these monthly increasing trends in thirdlevel basins were significant (Fig. S7).

\subsection{Future changes of snowmelt under different climate scenarios}

\subsubsection{Snowmelt}

The snowmelt in Northern Xinjiang and Northeast China showed a significant decreasing trend from 2006 to 2099 under RCP8.5, but showed no significant changes under RCP2.6 or RCP4.5. The snowmelt in the Tibetan Plateau and the whole of China showed significant decreasing trends from 2006 to 2099 under all three RCPs, with the most drastic decline being under RCP8.5 (Fig. 12). The changes in snowmelt in China and its three main stable snow cover regions in the 2030s, 2050s

415 and 2090s under the three RCPs were shown in Table 3. In Northern Xinjiang, the total projected snowmelt in these three decades under the three RCPs were not very different than the snowmelt in the historical period (1951-2017). The models projected that snowmelt would increase in low-elevation arid areas and decrease in the higher elevation Tianshan and Altai Mountains (Fig. 13). In Northeast China, the total projected snowmelts in different decades under the three RCPs were all lower than in the historical period. The model projected that snowmelt would increase in the Greater Khingan Range and the

420 Songliao Plain and decrease in the Lesser Khingan and Changbai mountains. In most areas of the Tibetan Plateau, the model projected a large decrease in snowmelt (Fig. 13). Under RCP2.6, RCP4.5 and RCP8.5, the snowmelt in the Tibetan Plateau in the 2030s $(2050 \mathrm{~s}, 2090 \mathrm{~s})$ was projected to decrease by $17.7 \%(18.7 \%, 16.8 \%), 20.4 \%(22.6 \%, 24.2 \%), 20.2 \%(27.0 \%$, $47.3 \%$ ) compared to the historical period. Southeast China was another area where snowmelt was projected to decrease to a 
large degree (Fig. 13). The model projected that the total snowmelt in China would decrease in different decades: under RCP2.6, RCP4.5 and RCP8.5, the projected decrease in snowmelt in China in the 2030s (2050s, 2090s) was 13.4\% (16.3\%, $13.8 \%), 19.1 \%(19.8 \%, 22.5 \%)$ and $17.1 \%(24.7 \%, 42.8 \%)$ compared to the historical period.

Table 3. Changes in mean annual air temperature $\left(T_{a},{ }^{\circ} \mathrm{C}\right)$, precipitation $(P, \mathrm{~mm})$ and snowmelt $\left(M, \times 10^{11} \mathrm{~m}^{3}\right)$ in China and its three main stable snow cover regions during various decades under the three representative concentration pathways (RCPs). Historical period: 1951-2017.

\begin{tabular}{|c|c|c|c|c|c|c|c|c|c|c|c|c|}
\hline \multirow{2}{*}{ Periods } & \multicolumn{3}{|c|}{ China } & \multicolumn{3}{|c|}{ Northern Xinjiang } & \multicolumn{3}{|c|}{ Northeast China } & \multicolumn{3}{|c|}{ Tibetan Plateau } \\
\hline & $T_{a}$ & $P$ & $M$ & $T_{a}$ & $P$ & $M$ & $T_{a}$ & $P$ & $M$ & $T_{a}$ & $P$ & $M$ \\
\hline Historical period & 6.31 & 573 & 2.41 & 5.28 & 166 & 0.18 & 2.25 & 491 & 0.42 & -2.66 & 355 & 1.15 \\
\hline $\mathrm{RCP} 2.6-2030 \mathrm{~s}$ & 7.54 & 589 & 2.09 & 7.00 & 180 & 0.18 & 3.88 & 530 & 0.42 & -1.56 & 384 & 0.95 \\
\hline RCP2.6-2050s & 7.74 & 609 & 2.02 & 7.31 & 176 & 0.18 & 4.05 & 540 & 0.39 & -1.37 & 392 & 0.94 \\
\hline RCP2.6-2090s & 7.63 & 602 & 2.08 & 6.96 & 183 & 0.19 & 4.02 & 529 & 0.41 & -1.53 & 395 & 0.96 \\
\hline $\mathrm{RCP} 4.5-2030 \mathrm{~s}$ & 7.65 & 585 & 1.95 & 7.10 & 177 & 0.18 & 4.05 & 519 & 0.39 & -1.48 & 382 & 0.92 \\
\hline $\mathrm{RCP} 4.5-2050 \mathrm{~s}$ & 8.20 & 601 & 1.93 & 7.79 & 176 & 0.17 & 4.65 & 539 & 0.41 & -0.95 & 400 & 0.89 \\
\hline $\mathrm{RCP} 4.5-2090 \mathrm{~s}$ & 8.71 & 624 & 1.87 & 8.41 & 189 & 0.18 & 5.39 & 539 & 0.38 & -0.55 & 417 & 0.87 \\
\hline $\mathrm{RCP} 8.5-2030 \mathrm{~s}$ & 7.78 & 581 & 2.00 & 7.33 & 181 & 0.18 & 4.13 & 514 & 0.41 & -1.31 & 385 & 0.92 \\
\hline RCP8.5-2050s & 8.80 & 610 & 1.82 & 8.62 & 180 & 0.17 & 5.37 & 536 & 0.39 & -0.40 & 406 & 0.84 \\
\hline RCP8.5-2090s & 11.19 & 638 & 1.38 & 11.45 & 188 & 0.15 & 8.31 & 596 & 0.34 & 1.78 & 436 & 0.61 \\
\hline
\end{tabular}


https://doi.org/10.5194/hess-2021-433

Preprint. Discussion started: 6 September 2021

(c) Author(s) 2021. CC BY 4.0 License.
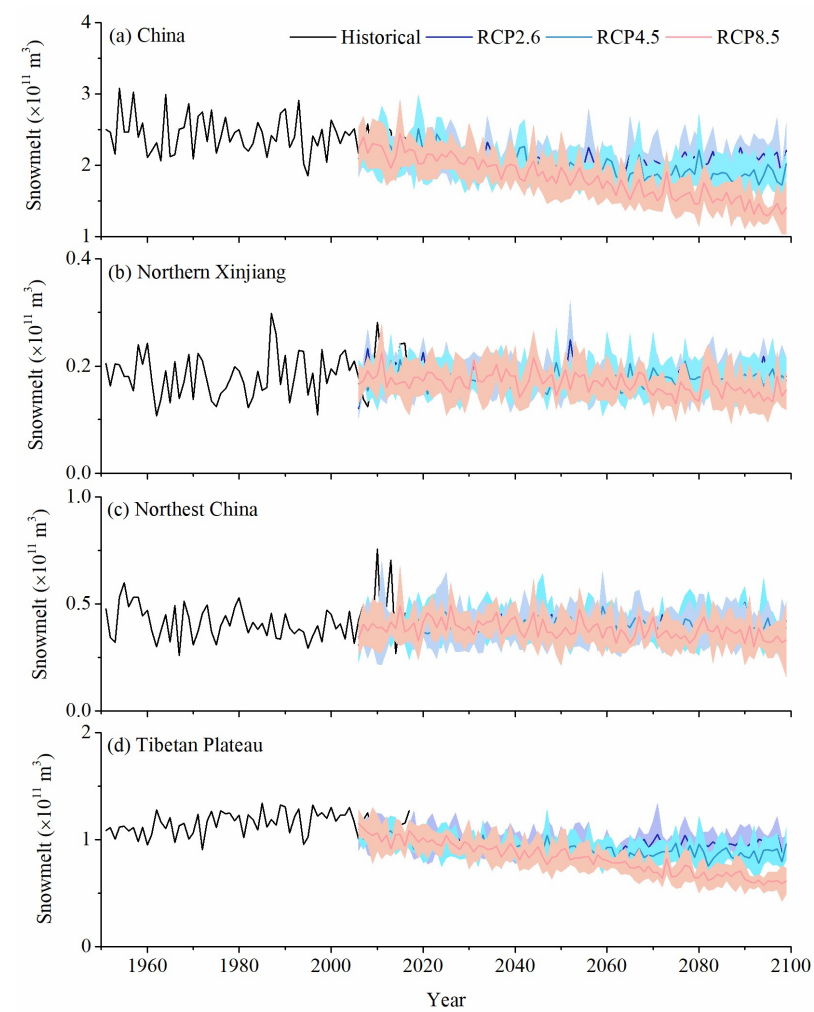

Figure 12. Projected future changes in snowmelt in China and its three main stable snow cover regions. Historical: 1951-2017; RCP: representative concentration pathway. 

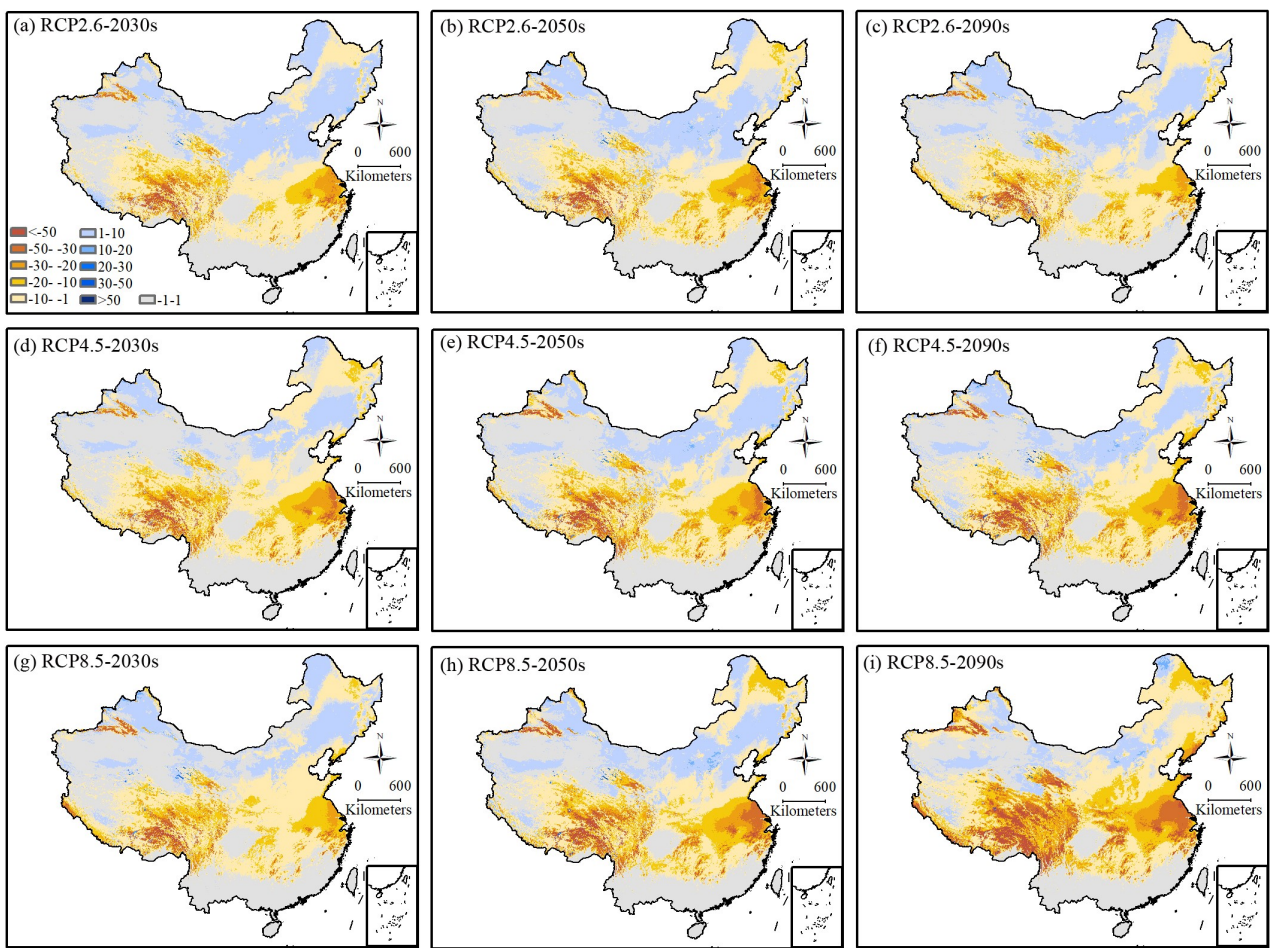

Figure 13. Spatial distributions of differences $(\mathrm{mm})$ between the projected mean annual snowmelt and the historical period (19512017) for the 2030s, 2050s and 2090s under RCP2.6, RCP4.5 and RCP8.5 in China.

\subsubsection{Snowmelt runoff ratio}

Under the three RCPs, the projected mean annual snowmelt runoff ratios in the third-level basins in different decades were mostly smaller than those in the historical period, except for a few basins in Southern Xinjiang and North China (Fig. 14). In general, the largest decreases in snowmelt runoff ratio in the basins were projected to occur by the 2090s, followed by the 2050s and 2030s. The largest decreases were projected under RCP8.5, followed by RCP4.5 and RCP2.6. Among the three main stable snow cover regions, the snowmelt runoff ratios were projected to decrease the most in basins in the Tibetan Plateau, followed by basins in Northern Xinjiang and Northeast China. Under RCP8.5, in the 2090s, the projected mean annual snowmelt runoff ratios were lower than those in the historical period in all basins except the three basins near the Taklimakan Desert, and the snowmelt runoff ratios in the Tibetan Plateau and Tianshan Mountains were projected to decrease by more than $5 \%$ in most basins and by more than $10 \%$ in a few basins relative to the historical period (Fig. 14i). 

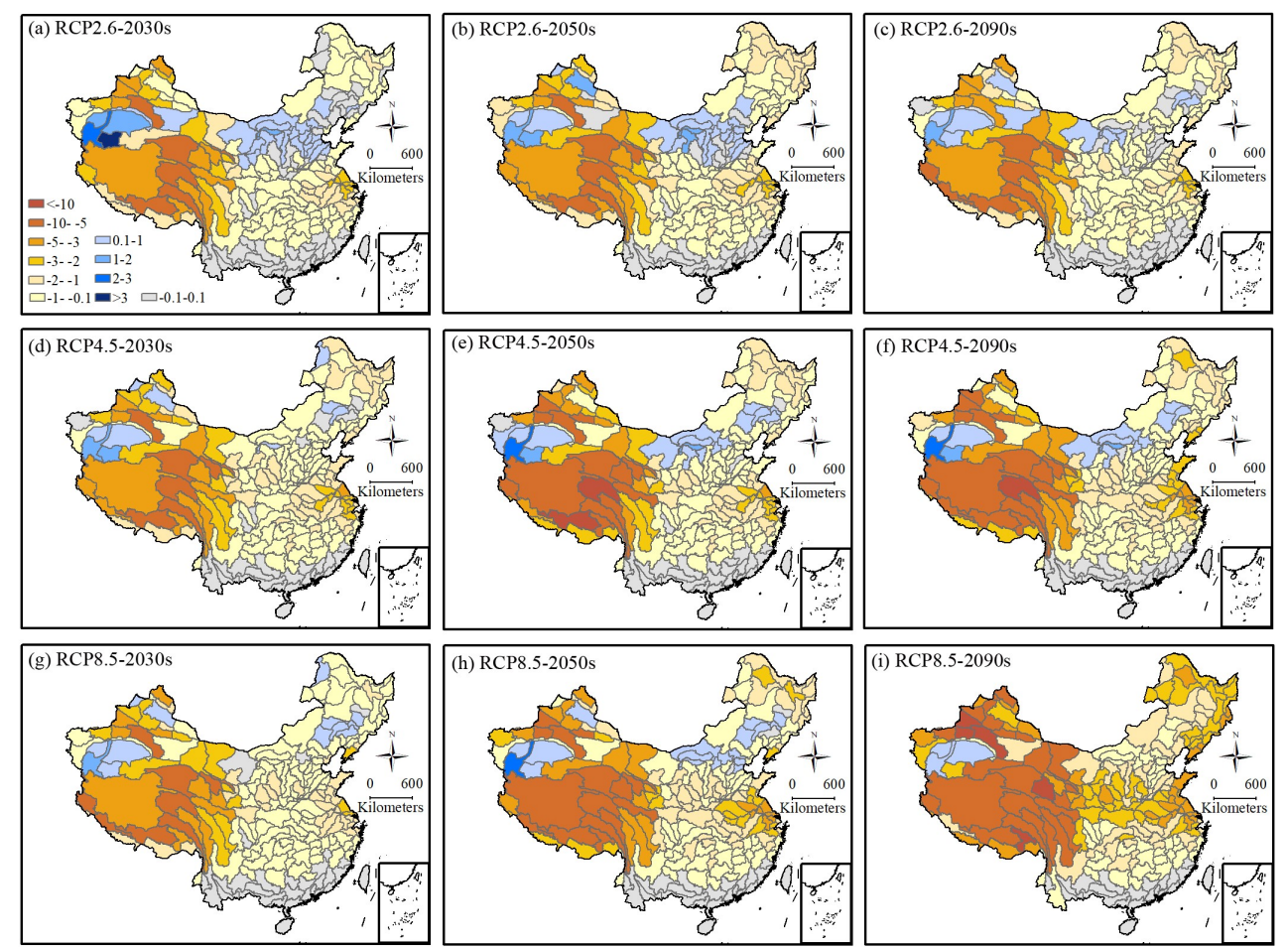

Figure 14. Spatial distributions of differences (\%) between the projected mean annual snowmelt runoff ratio and the historical period (1951-2017) for the 2030s, 2050s and 2090s under RCP2.6, RCP4.5 and RCP8.5 in China.

\section{Discussion}

\subsection{Model Evaluation}

Snowmelt is difficult to measure directly, and therefore, the model outputs of snowfall, snow depth, snow cover extent and snow water equivalent were selected to verify the model performance. Although the model was solely driven by air temperature and precipitation, the model outputs showed acceptable performance compared with the results from other studies. Han et al. (2021) used rainfall and snowfall temperature thresholds to identify precipitation types in the Lancang River basin in Southwest China, and obtained $R^{2}$ values between the simulated snowfall and the snowfall observed at three meteorological stations of $0.42,0.34$ and 0.61 , respectively; in this study, the $R^{2}$ values at the same stations were $0.72,0.46$ and 0.39 , respectively. Li et al. (2020) used temperature thresholds to calculate the snowfall in the Tianshan Mountains of Central Asia, and obtained a mean $R^{2}$ value between the simulated snowfall and the snowfall observed at 27 meteorological 
stations of 0.61 ; in this study, the mean $R^{2}$ value at 50 stations in Xingjiang was 0.39 . Zhong et al. (2018) discriminated the precipitation phase based on temperature thresholds in the Songhua River basin, Northeast China, and obtained $R^{2}$ values between simulated and observed snowfall of less than 0.3 for most meteorological stations; in this study, the $R^{2}$ was larger than 0.3 for most stations.

Snow depth was the worst-performing model output, this was mainly for the following reasons. (1) The model was performed on a monthly scale, whereas the output data were compared with the observed snow depth measured on the last day of each month, which increased the error. (2) The output data were at the grid scale, whereas the observed snow depth was at the site scale, where the snow properties were not always representative of snow at grid (Sexstone et al., 2020). (3) Snow depth itself is difficult to simulate, and even the snow depth retrieved by remote sensing have been shown to have high uncertainty. Orsolini et al. (2019) found that the mean annual snow depth at 33 meteorological stations in the Tibetan Plateau based on multiple global reanalysis products was $1.38 \mathrm{~cm}$ to $11.71 \mathrm{~cm}$, with a mean value of $7.88 \mathrm{~cm}$, while the observed snow depth was $0.23 \mathrm{~cm}$. Furthermore, Bin et al. (2013) evaluated snow depth obtained from five algorithms using AMSR-E passive microwave against ground observations from meteorological stations across China, and found that the RMSE varied from $6.85 \mathrm{~cm}$ to $16.79 \mathrm{~cm}$ in Xinjiang region, and from $6.21 \mathrm{~cm}$ to $18.05 \mathrm{~cm}$ in Northeast China. In this study, the RMSE varied from $0.56 \mathrm{~cm}$ to $13.32 \mathrm{~cm}$ in Xinjiang, and $0.54 \mathrm{~cm}$ to $9.00 \mathrm{~cm}$ in Northeast China. Additionally, many studies have shown that the retrieved snow depth is more accurate in regions with larger snow depth (e.g. Zhou et al., 2017; Wang and Zheng, 2020); and in this study, the performances in the regions with larger snow depth such as Northern Xinjiang and Northeast China were also much better than those in other regions.

480 Among the simulated snow properties, the snow cover extent showed the best performance, with $R^{2}$ and NSE values above 0.80 (Fig. 5). The performance of the snow water equivalent was acceptable in northern Xinjiang and Northeast China but was poor in the Tibetan Plateau (Fig. 6). There are several possible reasons for this difference. (1) The accuracy of the driving data of precipitation and temperature in the Tibetan Plateau was lower than that in other regions (Peng et al., 2019). (2) Due to the sparse distribution of meteorological stations in the Tibetan Plateau and the fact that most of these were located at low elevations, the reliability of the model parameters might be worse in this region than in other regions. (3) The snow water equivalent data used for verification have large uncertainties in the Tibetan Plateau because of its high elevation and complex terrain and climatic conditions (You et al., 2020).

In summary, the verification of snowfall, snow depth, snow cover extent and snow water equivalent suggests that the model was reliable for calculating the snowmelt in China.

\subsection{Influence of changes in temperature and precipitation on snowmelt}

Snowmelt is sensitive to both temperature and precipitation, and the relationship between snowmelt and warming is more complex than monotonic declines (Mankin et al., 2015). In China, climate warming has led to temperature increase, and snowmelt is increasing significantly in some regions (Fig. 7c). The grids with significant changes in snowmelt from 1951 to 2017 were selected to analyse the changes in air temperature, precipitation and snowfall (Fig. 15). In the regions where 

(increased) significantly in many regions where snowmelt increased (decreased) significantly. The regions with significant changes in snowmelt were relatively consistent with the regions with snowfall changes. There were no girds where snowfall increased significantly and snowmelt decreased significantly. In a few grids, snowfall decreased significantly and the snowmelt increased significantly. These grids were too few and could be ignored (Table S2). Compared with the total annual precipitation, the change of snowfall has more influence on snowmelt. Tan et al. (2019) analysed the relationship between snow cover days and precipitation in China and found that snow cover days were highly correlated with winter precipitation, but were not correlated with spring precipitation. In global climate models, there is more uncertainty about precipitation than temperature (Woldemeskel et al., 2016). Many assessments of precipitation from climate models were performed at the annual scale (e.g. Woldemeskel et al., 2016; Ahmed et al., 2019; Yue et al., 2019). Assessing precipitation from climate models using multiple time scales or seasons may allow a more accurate prediction of snowfall and snowmelt changes.

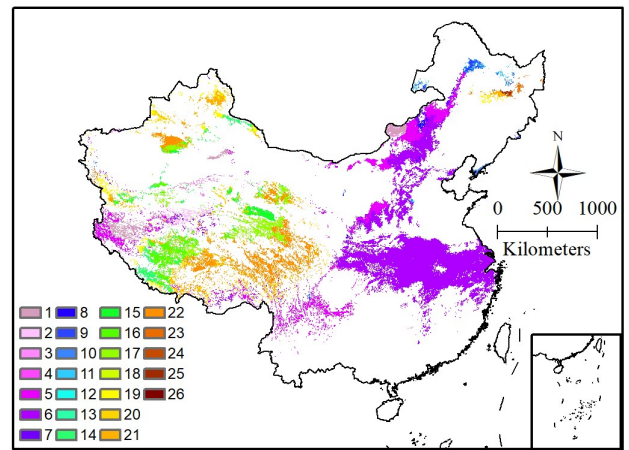

Figure 15. Trends of the annual snowmelt, precipitation, snowfall and air temperature based on the Mann-Kendall method in China during the 1951-2017 period. The meanings of the numbers in the legend are shown in Table S2.

As snow cover formation and snowmelt are closely related to the temperature threshold of $0{ }^{\circ} \mathrm{C}$, temperature change near $0{ }^{\circ} \mathrm{C}$

510 is more likely to trigger a drastic change in snowmelt. This may partly explain for the spatial distribution of snowmelt changes in China. In Northern Xinjiang and Northeast China, the main stable snow cover regions in China, the changes in snowmelt from 1951 to 2017 were not significant, and the future projections suggest that the changes in snowmelt in these regions will not be drastic. In these two regions, the snow season temperatures are well below the freezing (Qin et al., 2006), and the snowmelt trend depends on the snowfall trend rather than the temperature trend. There is no reason for snowmelt to change significantly when precipitation does not change significantly and temperature is still to remain well below freezing in those two regions. Therefore, in Northern Xinjiang and Northeast China, snowmelt is unlikely to change significantly when precipitation does not change significantly and the temperature remains well below freezing. In Southeast China, the snowmelt decreased significantly from 1951 to 2017, and the model projected that snowmelt will decrease further under $\mathrm{RCP} 2.6, \mathrm{RCP} 4.5$ and RCP8.5. The climate in this region is warm with average monthly temperatures near $0{ }^{\circ} \mathrm{C}$ in winter 
520 (Zeng et al., 2016). Precipitation types are sensitive to temperature increase, and under climate change, less precipitation falls as snow and snowmelt decreases. With high elevation and low temperature, the Tibetan Plateau experienced the most complex changes in snowmelt from 1951 to 2017. Temperature significantly increased in the Tibetan Plateau and the annual precipitation increased in most areas of the region (Kuang and Jiao, 2016). This study showed that the snowmelt in the Tibetan Plateau increased significantly from 1951 to 2017. High elevations tend to be colder and therefore can tolerate more warming (Livneh and Badger, 2020). The increased precipitation in the Tibetan Plateau may have offset the decrease in snowfall caused by the temperature increase, and precipitation may be a more influential control on snowmelt in that region than temperature. The results of CIMP5 models showed that the snowmelt in the Tibetan Plateau may decrease in the future. In this region, further warming could cause the temperature threshold for snow formation to be reached, resulting in less snowfall and snowmelt at medium and low elevations, and the temperature may become a more influential control on snowmelt.

\subsection{Impact of snowmelt change on regional water supply}

China's three main stable snow cover regions (Northern Xinjiang, Northeast China and the Tibetan Plateau) are located in three different climate areas (TCZ, TMZ and MPZ, respectively). Besides these three regions, the part of Southeast China (mainly the Huaihe River basin and the lower reaches of the Yangtze River) that is in the SMZ also has relatively high

535 snowmelt (Fig. 7a). In the following, we examine these four regions to shed light on the potential regional water supply problems that may be associated with changes in snowmelt under climate change.

\subsubsection{Northern Xinjiang}

Northern Xinjiang is located in the TCZ, and snowmelt is an important source of fresh water in this region (Chen et al., 2020; Wu et al., 2021). This study showed that between 1951 and 2017 the mean annual snowmelt runoff ratios in the third-level

540 basins in Northern Xinjiang were above $10 \%$ and exceeded $30 \%$ in some basins. Although the annual snowmelt showed a significant increasing trend from 1951 to 2017, the increase was mainly in November. Because of the earlier snowmelt time under climate warming, the monthly snowmelt increased in March and decreased significantly in April. The snowmelt runoff ratios in April were generally more than 30\%, also showed a significant decreasing trend. March and April are times of plant and crop cultivation, and the water requirements for agricultural irrigation therefore increase sharply in these months. The

545 shift of the snowmelt time may reduce the water that is available for agriculture because of the mismatch between snowmelt and crop-growing (Notarnicola, 2020), and changes in the snowmelt amount and timing may bring agricultural risks in the Northern Xinjiang.

\subsubsection{Northeast China}

In Northeast China, the runoff in March and April is mainly generated from snowmelt. From 1951 to 2017, snowmelt in March increased while that in April decreased significantly. Due to its location in the TMZ, which has high levels of 
precipitation, the snowmelt runoff ratios in the basins in Northeast China are generally about $10 \%$, and the importance of snowmelt as a water resource in this region may be less than in Northern Xinjiang. However, because of the cold and long winter, snow plays a role as a natural reservoir to store water in winter, and snow melting releases water in spring, which can influence agriculture by affecting soil moisture (Qi et al., 2020). Snowmelt is vital for seasonal water supply in Northeast China, which is an important region for agricultural production in China. Because of the changes in snowmelt documented in this study, changes in water resource allocation in spring should be considered to meet the demands of spring crop planting.

\subsubsection{Tibetan Plateau}

The Tibetan Plateau is known as the "water tower" of Asia, since many of the continent's major rivers originate there (e.g. the Yangtze, Yellow, Indus, Mekong, Brahmaputra, Salween and Ganges rivers). The western and northern parts of the Tibetan Plateau are the source of many arid inland rivers such as the Hetian and Heihe rivers. Additionally, the Tibetan Plateau contains arid inland basins (e.g. the Qiangtang inland basin). These waters from the Tibetan Plateau have been sustaining life, agricultural, and industrial water usage for nearly $40 \%$ of the world's population (Xu et al., 2008). Due to its high elevation and low temperature, the mean annual snowmelt runoff ratios in the basins of the Tibetan Plateau are generally greater than $10 \%$. Snowmelt contributes runoff every month, and in some months all of the runoff is contributed by snowmelt. The snowmelt in the Tibetan Plateau showed an increasing trend from 1951 to 2017, and as the temperature is projected to rises further in the future, it is likely that both the snowmelt and snowmelt runoff ratio will decrease in the near future. Other studies have similarly concluded that the snowmelt and snowmelt runoff ratio in the Tibetan Plateau will decline in the future (Qin et al., 2020; Kraaijenbrink et al., 2021). The Tibetan Plateau and its surrounding downstream areas are projected to experience declines in the share of water from snowmelt and will thus require increases in alternative water supplies.

\subsubsection{Southeast China}

Southeast China is located in the SMZ, where precipitation is relatively high. The snowfall in winter is high, resulting in a large amount of snowmelt in this region. However, due to this region's high precipitation, snowmelt contributes relatively little to its water resources, with the snowmelt runoff ratios being less than $2 \%$ in most basins. Although climate change has caused a significant decrease in snowmelt in this region, and this trend is projected to continue in the future, the impact on water supply is likely to be much smaller than in other regions of China. The increased frequency and intensity of flooding that are projected to be caused by climate change is a major concern for this region (Qin and Lu, 2014).

\subsection{Uncertainties and limitations}

580 The snowmelt simulation reported in this study was largely driven by the climatology dataset of WorldClim using delta spatial downscaling, and any uncertainties in the dataset were likely to propagate to the snowmelt simulation. Many studies 
showed that, although the WorldClim data were adequate for air temperatures, there were large errors in its precipitation data, especially in mountainous areas with complex topography and high elevations (Beck et al., 2020; Bobrowski et al., 2021). Although the downscaled dataset generated by bilinear interpolation method containing detailed topographic information, as well as the effects of distance to the nearest coast and satellite-derived covariates, was of high quality, there was still a gap between the downscaled data and the observed data, especially in the mountainous areas (Peng et al., 2019; Ding and Peng, 2020). Uncertainties in the CIMP5 models (Woldemeskel et al., 2016) and the downscaling method (Lima et al., 2021) might introduce uncertainties in the assessments of future changes in snowmelt.

As the results of this study were based on simple temperature index model simulations, the uncertainty arising from the model parameterization needs to be addressed. There were three important parameters in the model: the threshold temperatures for the separation of rainfall and snowfall $\left(T_{\text {rain }}\right.$ and $\left.T_{\text {snow }}\right)$, the degree-day factors $(D D F)$ and the ratio of snow sublimation to snow accumulation $(k)$. Although $T_{\text {rain }}$ and $T_{\text {snow }}$ were derived from observations at meteorological stations, errors and uncertainties may have been increased when the values were interpolated into the grid. The $D D F$ was estimated using an empirical method that depends on the snow density observed at meteorological stations. Due to the uneven distribution of meteorological stations, especially few and sparse meteorological stations in the Tibetan Plateau, and the uncertainties introduced by the spatial interpolation of data from meteorological stations (Zhang and Ma, 2018), the errors of these parameters may have led to the uncertainty in the snowmelt calculation. Additionally, snow sublimation is very difficult quantify by measurement or modelling (Stigter et al., 2018). Due to the limited data availability and the complexity of snow sublimation, this study used the ratio of snow sublimation to snow accumulation to simplify the calculation of sublimation. However, this ratio can vary considerably both spatially and temporally, having been estimated to vary between 0.1 and $90 \%$ around the world (Stigter et al., 2018). The simplified calculation of snow sublimation and the failure to consider the monthly variability of this parameter may have increased the uncertainty of the snowmelt calculation.

Moreover, there are many glaciers in West China, and there are differences in the processes and parameters of glacier melting and snow melting (Terink et al., 2015; Armstrong et al., 2018). In this study, snowmelt was not clearly distinguished in the glacier area, which is another source of uncertainty in the snowmelt calculation.

In addition to snowmelt, the snowmelt runoff ratio was another important research object in this study. We estimated this ratio using snowmelt / (snowmelt + rainfall). However, this method may underestimate the ratio because snowmelt is more effective at generating catchment runoff than rainfall (Li et al., 2017; Jenicek and Ledvinka, 2020).

\section{Conclusions}

610 A simple temperature index model was used to calculate a time series of monthly snowmelt at a resolution of 0.5 seconds in China for the 1951-2017 period. The mean annual snowmelt in China was $2.41 \times 10^{11} \mathrm{~m}^{3}$, and the mean annual snowmelt in Northern Xinjiang, Northeast China and Tibetan Plateau was approximately $0.18 \times 10^{11} \mathrm{~m}^{3}, 0.42 \times 10^{11} \mathrm{~m}^{3}$ and $1.15 \times 10^{11} \mathrm{~m}^{3}$, respectively. From 1951 to 2017 , the annual snowmelt increased significantly in the Tibetan Plateau, and decreased 
significantly in the North, Central and Southeast China. There was a decreasing trend in snowmelt in China, although this trend was not statistically significant. In West China, the mean annual snowmelt runoff ratio was more than $10 \%$ in almost all third-level basins, except for those in the Taklimakan Desert. In basins in North and Northeast China, the snowmelt runoff ratio was generally more than $5 \%$, whereas in basins in South China it was less than $2 \%$. The Sen's slope showed that from 1951 to 2017, the annual snowmelt runoff ratio decreased in most third-level basins in China, where this decrease was significant were mainly distributed in central Inner Mongolia, the southern slopes of the Tianshan Mountains and South

Under RCP2.6, RCP4.5 and RCP8.5, the snowmelt in China showed a significant decreasing trend from 2006 to 2099, and the projected decrease in snowmelt in the 2030s $(2050 \mathrm{~s}, 2090 \mathrm{~s})$ was $13.4 \%(16.3 \%, 13.8 \%), 19.1 \%(19.8 \%, 22.5 \%), 17.1 \%$ $(24.7 \%, 42.8 \%)$ compared to the historical period (1951-2005), respectively. Among China's three main stable snow cover regions, the Tibetan Plateau was projected to experience the largest decrease in snowmelt in the future, followed by Northeast China; the snowmelt in the Northern Xinjiang was not projected to change significantly in the future. Under the three RCPs, the projected mean annual snowmelt runoff ratios in the third-level basins in different decades were less than those in the historical period, except for a few basins in Southern Xinjiang and North China, with the largest decrease projected to occur in the Tibetan Plateau.

This study also investigated the spatial variability of snowmelt changes caused by changes in temperature and precipitation. It found that in low temperature regions (which can tolerate more warming), the snowmelt change was mainly influenced by precipitation, whereas in warm regions, snowmelt change was most sensitive to temperature increases. The spatial variability of snowmelt changes may lead to the regional differences in the impact of snowmelt on water supply.

Although some uncertainties were introduced by the model principles, driving data and parameterization and other factors, this study is the first attempt to quantify snowmelt and its changes in China. Given the importance of snowmelt, the results

635 have important implications for future researches on snow-hydrology-climate interactions and contribute to water resource management planning under climate change.

Data availability. The spatial resolution with 0.5 seconds, including monthly minimum, maximum, and mean temperatures ( $T_{\min }, \quad T_{\max }$, and $T_{a}$ ) and precipitation, are obtained from Network Common Data Form at 640 https://doi.org/10.5281/zenodo.3114194 for precipitation and https://doi.org/10.5281/zenodo.3185722 for air temperatures. The air temperature, snowfall, snow depth and snow density observation data are obtained from the China Meteorological Administration (http://data.cma.cn/). The snow depth dataset derived from passive microwave remote sensing data is obtained by the National Tibetan Plateau Data Center (http://data.tpdc.ac.cn). The snow water equivalent dataset derived from passive microwave remote sensing data is obtained by the National Cryosphere Desert Data Center (https://www.ncdc.ac.cn). The CMIP5 data set is distributed by the Inter-Sectoral Impact Model Intercomparison Project on 
its own website (http://www.isi-mip.org). The third-level basins dataset is obtained by the Resource and Environment Science and Data Center (https://www.resdc.cn/).

Author contributions. RC initiated the study. YY, RC and GL developed the methodology. YY performed all analyses. YY and ZL prepared the input meteorological data. GL and XW prepared the CIMP5 models data. YY prepared the manuscript with contributions from RC.

Competing interests. The authors declare that they have no conflict of interest.

Acknowledgments. The authors would like to acknowledge data from the Network Common Data Form, China Meteorological Administration, National Tibetan Plateau Data Center, National Cryosphere Desert Data Center, Resource and Environment Science and Data Center, and Inter-Sectoral Impact Model Intercomparison Project. The authors would like to thank Prof. Xiongfeng Li for providing the snow cover classification in China, and Dr. Chuntan Han for providing the rain/snow separation threshold temperatures in China. This work was carried out with financial support from the National Key Research and Development Project (2019YFC1510505), National Natural Sciences Foundation of China (41690141), Joint Research Project of Three-River Headwaters National Park, Chinese Academy of Sciences and the People's Government of Qinghai Province (LHZX-2020-11), and National Natural Sciences Foundation of China (41901084).

\section{References}

Ahmed, K., Sachindra, D. A., Shahid, S., Demirel, M. C., and Chung, E.: Selection of multi-model ensemble of general circulation models for the simulation of precipitation and maximum and minimum temperature based on spatial assessment metrics, Hydrol. Earth Syst. Sci., 23, 4803-4824, https://doi.org/10.5194/hess-23-4803-2019, 2019.

Armstrong, R. L., Rittger, K., Brodzik, M. J., Racoviteanu, A., Barrett, A. P., Khalsa, S. S., Raup, B., Hill, A. F., Khan, A. L., Wilson, A. M., Kayastha, R. B., Fetterer, F., and Armstrong, B.: Runoff from glacier ice and seasonal snow in High Asia: separating melt water sources in river flow, Reg. Environ. Change, 19, 1249-1261, https://doi.org/10.1007/s10113-018-1429-0, 2018.

Barnett, T. P., Adam, J. C., and Lettenmaier, D. P.: Potential impacts of a warming climate on water availability in snowdominated regions, Nature, 438, 303-309, https://doi.org/10.1038/nature04141, 2005.

Barnhart, T. B., Tague, C. L., and Molotch, N. P.: The counteracting effects of snowmelt rate and timing on runoff, Water Resour. Res., 56, e2019WR026634, https://doi.org/10.1029/2019wr026634, 2020.

Beck, H. E., Wood, E. F., McVicar, T. R., Zambrano-Bigiarini, M., Alvarez-Garreton, C., Baez-Villanueva, O. M., Sheffield, J., and Karger, D. N.: Bias correction of global high-resolution precipitation climatologies using streamflow observations from 9372 catchments, J. Climate, 33, 1299-1315, https://doi.org/10.1175/jcli-d-19-0332.1, 2020.

Berghuijs, W. R., Woods, R. A., and Hrachowitz, M.: A precipitation shift from snow towards rain leads to a decrease in streamflow, Nat. Clim. Change, 4, 583-586, https://doi.org/10.1038/nclimate2246, 2014.

Bin, C., Qiu, Y., Shi, L., Chu, D., and Zhu, J.: Comparative validation of snow depth algorithms using AMSR-E passive microwave data in China, J. Glaciol. Geocryol., 35, 801-813, https://doi.org/10.7522/j.issn.1000-0240.2013.0091, 2013 (in Chinese). 
Bloschl, G., Hall, J., Viglione, A., Perdigao, R. A. P., Parajka, J., Merz, B., Lun, D., Arheimer, B., Aronica, G. T., Bilibashi, A., Bohac, M., Bonacci, O., Borga, M., Canjevac, I., Castellarin, A., Chirico, G. B., Claps, P., Frolova, N., Ganora, D., Gorbachova, L., Gul, A., Hannaford, J., Harrigan, S., Kireeva, M., Kiss, A., Kjeldsen, T. R., Kohnova, S., Koskela, J. J., Ledvinka, O., Macdonald, N., Mavrova-Guirguinova, M., Mediero, L., Merz, R., Molnar, P., Montanari, A., Murphy, C., Osuch, M., Ovcharuk, V., Radevski, I., Salinas, J. L., Sauquet, E., Sraj, M., Szolgay, J., Volpi, E., Wilson, D., Zaimi, K., and Zivkovic, N.: Changing climate both increases and decreases European river floods, Nature, 573, 108-111, https://doi.org/10.1038/s41586-019-1495-6, 2019.

Bobrowski, M., Weidinger, J., and Schickhoff, U.: Is new always better? Frontiers in global climate datasets for modeling treeline species in the Himalayas, Atmosphere, 12, https://doi.org/10.3390/atmos12050543, 2021.

Che, T., Li, X., Jin, R., Armstrong, R., and Zhang, T.: Snow depth derived from passive microwave remote-sensing data in China, Ann. Glaciol., 49, 145-154, https://doi.org/10.3189/172756408787814690, 2008.

Chen, H., Chen, Y., Li, W., and Li, Z.: Quantifying the contributions of snow/glacier meltwater to river runoff in the Tianshan Mountains, Central Asia, Glob. Planet. Chang, 174, 47-57, https://doi.org/10.1016/j.gloplacha.2019.01.002, 2019.

Chen, W., Ding, J., Wang, J., Zhang, J., and Zhang, Z.: Temporal and spatial variability in snow cover over the Xinjiang Uygur Autonomous Region, China, from 2001 to 2015, PeerJ, 8, e8861, https://doi.org/10.7717/peerj.8861, 2020.

Chen, X., Liang, S., Cao, Y., and He, T.: Distribution, attribution, and radiative forcing of snow cover changes over China from 1982 to 2013, Clim. Change, 137, 363-377, https://doi.org/10.1007/s10584-016-1688-z, 2016.

Dai, L. and Chen, T.: The spatio-temporal distribution of snow density and its influence factors from 1999 to 2008 in China, J. Glaciol. Geocryol., 32, 861-866, 2010 (in Chinese).

Dai, L., Che, T., Wang, J., and Zhang, P.: Snow depth and snow water equivalent estimation from AMSR-E data based on a priori snow characteristics in Xinjiang, China, Remote Sens. Environ., 127, 14-29, https://doi.org/10.1016/j.rse.2011.08.029, 2012.

Ding, Y. and Peng, S.: Spatiotemporal trends and attribution of drought across China from 1901-2100, Sustainability, 12, 477, https://doi.org/10.3390/su12020477, 2020.

705 Ficklin, D. L., Letsinger, S. L., Stewart, I. T., and Maurer, E. P.: Assessing differences in snowmelt-dependent hydrologic projections using CMIP3 and CMIP5 climate forcing data for the western United States, Hydrol. Res., 47, 483-500, https://doi.org/10.2166/nh.2015.101, 2016.

Han, C., Cheng, R., Liu, J., Yang, Y., and Qing, W.: A discuss of the separating solid and liquid precipitations, J. Glaciol. Geocryol., 32, 249-256, 2010 (in Chinese).

710 Han, Z., Long, D., Han, P., Huang, Q., Du, M., and Hou, A.: An improved modeling of precipitation phase and snow in the Lancang River Basin in Southwest China, Sci. China Technol. Sci., 64, 1513-1527, https://doi.org/10.1007/s11431-0201788-4, 2021.

Hargreaves, G. H. and Samani, Z. A.: Reference crop evapotranspiration from temperature, Appl. Eng. Agric., 1, 96-99, https://doi.org/10.13031/2013.26773, 1985.

715 Hempel, S., Frieler, K., Warszawski, L., Schewe, J., and Piontek, F.: A trend-preserving bias correction-the ISI-MIP approach, Earth Syst. Dynam., 4, 219-236, https://doi.org/10.5194/esd-4-219-2013, 2013.

Hock, R.: Temperature index melt modelling in mountain areas, J. Hydrol., 282, 104-115, https://doi.org/10.1016/s00221694(03)00257-9, 2003.

Immerzeel, W. W., van Beek, L. P. H., and Bierkens, M. F. P.: Climate change will affect the Asian water towers, Science, 328, 1382-1385, https://doi.org/10.1126/science.1183188, 2010.

Immerzeel, W. W., van Beek, L. P., Konz, M., Shrestha, A. B., and Bierkens, M. F.: Hydrological response to climate change in a glacierized catchment in the Himalayas, Clim. Change, 110, 721-736, https://doi.org/10.1007/s10584-011-0143-4, 2012 .

Jenicek, M. and Ledvinka, O.: Importance of snowmelt contribution to seasonal runoff and summer low flows in Czechia, Hydrol. Earth Syst. Sci., 24, 3475-3491, https://doi.org/10.5194/hess-24-3475-2020, 2020.

Jiang, L., Wang, P., Zhang, L., Yang, H., and Yang, J.: Improvement of snow depth retrieval for FY3B-MWRI in China, Sci. China Earth Sci., 57, 1278-1292, https://doi.org/10.1007/s11430-013-4798-8, 2014.

Jost, G., Dan Moore, R., Smith, R., and Gluns, D. R.: Distributed temperature-index snowmelt modelling for forested catchments, J. Hydrol., 420-421, 87-101, https://doi.org/10.1016/j.jhydrol.2011.11.045, 2012. 
730 Ke, C., Li, X., Xie, H., Ma, D., Liu, X., and Kou, C.: Variability in snow cover phenology in China from 1952 to 2010 , Hydrol. Earth Syst. Sci., 20, 755-770, https://doi.org/10.5194/hess-20-755-2016, 2016.

Kendall, M. G.: Rank Correlation Methods (4th ed.), Charles Griffin, London, 1975.

Kraaijenbrink, P. D. A., Stigter, E. E., Yao, T., and Immerzeel, W. W.: Climate change decisive for Asia's snow meltwater supply, Nat. Clim. Change, 11, 591-597, https://doi.org/10.1038/s41558-021-01074-x, 2021.

735 Kuang, X. and Jiao, J. J.: Review on climate change on the Tibetan Plateau during the last half century, J. Geophys. Res. Atmos., 121, 3979-4007, https://doi.org/10.1002/2015jd024728, 2016.

Li, D., Wrzesien, M. L., Durand, M., Adam, J., and Lettenmaier, D. P.: How much runoff originates as snow in the western United States, and how will that change in the future?, Geophys. Res. Lett., 44, 6163-6172, https://doi.org/10.1002/2017g1073551, 2017. 740 Li, H., Zhang, Y., Li, X., Yang, D., and Hao, X.: Tracing snowmelt paths in an integrated hydrological model for
understanding seasonal snowmelt contribution at basin scale, J. Geophys. Res. Atmos., 124, 8874-8895, https://doi.org/10.1029/2019JD030760, 2019.

Li, S., Liu, M., Adam, J. C., Pi, H., Su, F., Li, D., Liu, Z., and Yao, Z.: Contribution of snow-melt water to the streamflow over the Three-River headwater region, China, Remote Sens., 13, 1585, https://doi.org/10.3390/rs13081585, 2021.

$745 \mathrm{Li}, \mathrm{X}$., Liang, S., Zhao, K., Wang, J., Che, T., and Li, Z.: Snow cover classification based on climate variables and its distribution characteristics in China, J. Glaciol. Geocryol., 42, 62-71, https://doi.org/10.7522/j. issn. 1000-0240. 2019. 0055, 2020 (in Chinese).

Li, Z., Chen, Y., Li, Y., and Wang, Y.: Declining snowfall fraction in the alpine regions, Central Asia, Sci. Rep., 10, 3476, https://doi.org/10.1038/s41598-020-60303-z, 2020.

750 Lima, C. H. R., Kwon, H., and Kim, Y.: A Bayesian Kriging model applied for spatial downscaling of daily rainfall from GCMs, J. Hydrol., 597, 126095, https://doi.org/10.1016/j.jhydrol.2021.126095, 2021.

Liu, G., Chen, R., and Wang, X.: Spatial and temporal variability in positive degree-day in Western China under climate change, Atmosphere, 12, 443, https://doi.org/10.3390/atmos12040443, 2021.

755 Liu, Y., Xu, J., Lu, X., and Nie, L.: Assessment of glacier- and snowmelt- driven streamflow in the

Livneh, B. and Badger, A. M.: Drought less predictable under declining future snowpack, Nat. Clim. Change, 10, 452-458, https://doi.org/10.1038/s41558-020-0754-8, 2020.

Lopez, M. G., Vis, M. J. P., Jenicek, M., Griessinger, N., and Seibert, J.: Assessing the degree of detail of temperature-based snow routines for runoff modelling in mountainous areas in central Europe, Hydrol. Earth Syst. Sci., 24, 4441-4461, https://doi.org/10.5194/hess-24-4441-2020, 2020.

Ma, N., Yu, K., Zhang, Y., Zhai, J., Zhang, Y., and Zhang, H.: Ground observed climatology and trend in snow cover phenology across China with consideration of snow-free breaks, Clim. Dyn., 55, 2867-2887, https://doi.org/10.1007/s00382-020-05422-z, 2020.

Mankin, J. S., Viviroli, D., Singh, D., Hoekstra, A. Y., and Diffenbaugh, N. S.: The potential for snow to supply human water demand in the present and future, Environ. Res. Lett., 10, 114016, https://doi.org/10.1088/1748-9326/10/11/114016, 2015.

Mann, H. B.: Nonparametric tests against trend, Econometrica, 13, 245-259, https://doi.org/10.2307/1907187, 1945.

Musselman, K. N., Clark, M. P., Liu, C., Ikeda, K., and Rasmussen, R.: Slower snowmelt in a warmer world, Nat. Clim. Change, 7, 214-219, https://doi.org/10.1038/nclimate3225, 2017.

770 Notarnicola, C.: Observing snow cover and water resource changes in the high mountain Asia region in comparison with global mountain trends over 2000-2018, Remote Sens., 12, 3913, https://doi.org/10.3390/rs12233913, 2020.

Orsolini, Y., Wegmann, M., Dutra, E., Liu, B., Balsamo, G., Yang, K., de Rosnay, P., Zhu, C., Wang, W., Senan, R., and Arduini, G.: Evaluation of snow depth and snow cover over the Tibetan Plateau in global reanalyses using in situ and satellite remote sensing observations, Cryosphere, 13, 2221-2239, https://doi.org/10.5194/tc-13-2221-2019, 2019.

775 Peng, S., Ding, Y., Liu, W., and Li, Z.: $1 \mathrm{~km}$ monthly temperature and precipitation dataset for China from 1901 to 2017 , Earth Syst. Sci. Data, 11, 1931-1946, https://doi.org/10.5194/essd-11-1931-2019, 2019.

Pulliainen, J., Luojus, K., Derksen, C., Mudryk, L., Lemmetyinen, J., Salminen, M., Ikonen, J., Takala, M., Cohen, J., Smolander, T., and Norberg, J.: Patterns and trends of Northern Hemisphere snow mass from 1980 to 2018, Nature, 581, 294-298, https://doi.org/10.1038/s41586-020-2258-0, 2020. 
780 Qi, W., Feng, L., Liu, J., and Yang, H.: Snow as an important natural reservoir for runoff and soil moisture in Northeast China, J. Geophys. Res. Atmos., 125, e2020JD033086, https://doi.org/10.1029/2020jd033086, 2020.

Qin, D., Liu, S., and Li, P.: Snow cover distribution, variability, and response to climate change in Western China, J. Climate, 19, 1820-1833, https://doi.org/10.1175/jcli3694.1, 2006.

Qin, X. S. and Lu, Y.: Study of climate change impact on flood frequencies: a combined weather generator and hydrological modeling approach, J. Hydrometeorol., 15, 1205-1219, https://doi.org/10.1175/jhm-d-13-0126.1, 2014.

Qin, Y., Abatzoglou, J. T., Siebert, S., Huning, L. S., AghaKouchak, A., Mankin, J. S., Hong, C., Tong, D., Davis, S. J., and Mueller, N. D.: Agricultural risks from changing snowmelt, Nat. Clim. Change, 10, 459-465, https://doi.org/10.1038/s41558-020-0746-8, 2020.

Rajkumari, S., Chiphang, N., Kiba, L. G., Bandyopadhyay, A., and Bhadra, A.: Development and application of a spatially distributed snowmelt runoff model for limited data condition, Arab. J. Geosci., 12, 488, https://doi.org/10.1007/s12517019-4661-0, 2019.

Sen, P. K.: Estimates of the regression coefficient based on Kendall's Tau, J. Am. Stat. Assoc., 63, 1379-1389, https://doi.org/10.1080/01621459.1968.10480934, 1968.

Sexstone, G. A., Penn, C. A., Liston, G. E., Gleason, K. E., Moeser, C. D., and Clow, D. W.: Spatial variability in seasonal snowpack trends across the Rio Grande headwaters (1984-2017), J. Hydrometeorol., 21, 2713-2733, https://doi.org/10.1175/jhm-d-20-0077.1, 2020.

Sexstone, G. A., Clow, D. W., Fassnacht, S. R., Liston, G. E., Hiemstra, C. A., Knowles, J. F., and Penn, C. A.: Snow sublimation in mountain environments and Its sensitivity to forest disturbance and climate warming, Water Resour. Res., 54, 1191-1211, https://doi.org/10.1002/2017wr021172, 2018.

Skaugen, T., Luijting, H., Saloranta, T., Vikhamar-Schuler, D., and Müller, K.: In search of operational snow model structures for the future-comparing four snow models for 17 catchments in Norway, Hydrol. Res., 49, 1929-1945, https://doi.org/10.2166/nh.2018.198, 2018.

Stigter, E. E., Litt, M., Steiner, J. F., Bonekamp, P. N. J., Shea, J. M., Bierkens, M. F. P., and Immerzeel, W. W.: The importance of snow sublimation on a Himalayan glacier, Front. Earth Sci., 6, 108, https://doi.org/10.3389/feart.2018.00108, 2018.

Svoma, B. M.: Difficulties in determining snowpack sublimation in complex terrain at the macroscale, Adv. Meteorol., 2016, 1-10, https://doi.org/10.1155/2016/9695757, 2016.

Tan, X., Wu, Z., Mu, X., Gao, P., Zhao, G., Sun, W., and Gu, C.: Spatiotemporal changes in snow cover over China during 1960-2013, Atmos. Res., 218, 183-194, https://doi.org/10.1016/j.atmosres.2018.11.018, 2019.

810 Terink, W., Lutz, A. F., Simons, G. W. H., Immerzeel, W. W., and Droogers, P.: SPHY v2.0: Spatial processes in hydrology, Geosci. Model Dev., 8, 2009-2034, https://doi.org/10.5194/gmd-8-2009-2015, 2015.

Vano, J. A.: Implications of losing snowpack, Nat. Clim. Change, 10, 388-389, https://doi.org/10.1038/s41558-020-0760-x, 2020.

Vormoor, K., Lawrence, D., Schlichting, L., Wilson, D., and Wong, W. K.: Evidence for changes in the magnitude and frequency of observed rainfall vs. snowmelt driven floods in Norway, J. Hydrol., 538, 33-48, https://doi.org/10.1016/j.jhydrol.2016.03.066, 2016.

Wake, L. M. and Marshall, S. J.: Assessment of current methods of positive degree-day calculation using in situ observations from glaciated regions, J. Glaciol., 61, 329-344, https://doi.org/10.3189/2015JoG14J116, 2017.

820 recent 50 years, J. Glaciol. Geocryol., 34, 247-256, 2012 (in Chinese).

Wang, Y. and Zheng, Z.: Spatial representativeness analysis for snow depth measurements of meteorological stations in Northeast China, J. Hydrometeorol., 21, 791-805, https://doi.org/10.1175/jhm-d-19-0134.1, 2020.

Woldemeskel, F. M., Sharma, A., Sivakumar, B., and Mehrotra, R.: Quantification of precipitation and temperature uncertainties simulated by CMIP3 and CMIP5 models, J. Geophys. Res. Atmos., 121, 3-17, https://doi.org/10.1002/2015jd023719, 2016.

Wu, X., Wang, X., Liu, S., Yang, Y., Xu, G., Xu, Y., Jiang, T., and Xiao, C.: Snow cover loss compounding the future economic vulnerability of western China, Sci. Total Environ., 755, 143025, https://doi.org/10.1016/j.scitotenv.2020.143025, 2021.

Xu, X., Lu, C., Shi, X., and Gao, S.: World water tower: An atmospheric perspective, Geophys. Res. Lett., 35, L20815, 

https://doi.org/10.1029/2008g1035867, 2008.

Yang, J., Jiang, L., Wu, S., Wang, G., Wang, J., and Liu, X.: Development of a snow depth estimation algorithm over China for the FY-3D/MWRI, Remote Sens., 11, 977, https://doi.org/10.3390/rs11080977, 2019.

Yang, J. W., Jiang, L. M., Lemmetyinen, J., Luojus, K., Takala, M., Wu, S. L., and Pan, J. M.: Validation of remotely sensed estimates of snow water equivalent using multiple reference datasets from the middle and high latitudes of China, J. Hydrol., 590, 125499, https://doi.org/10.1016/j.jhydrol.2020.125499, 2020.

Yang, Y., Chen, R., Han, C., and Liu, Z.: Evaluation of 18 models for calculating potential evapotranspiration in different climatic zones of China, Agric. Water Manage., 244, 106545, https://doi.org/10.1016/j.agwat.2020.106545, 2021.

You, Q., Wu, T., Shen, L., Pepin, N., Zhang, L., Jiang, Z., Wu, Z., Kang, S., and AghaKouchak, A.: Review of snow cover variation over the Tibetan Plateau and its influence on the broad climate system, Earth-Sci. Rev., 201, 103043, https://doi.org/10.1016/j.earscirev.2019.103043, 2020.

Yue, T. X., Zhao, N., Fan, Z. M., Li, J., Chen, C. F., Lu, Y. M., Wang, C. L., Gao, J., Xu, B., Jiao, Y. M., and Wilson, J. P.: Methods for simulating climate scenarios with improved spatiotemporal specificity and less uncertainty, Glob. Planet. Chang, 181, 102973, https://doi.org/10.1016/j.gloplacha.2019.05.013, 2019.

Zeng, B., Yan, C., and Yu, L.: Analysis of winter temperature in South China during 1960-2009, Plateau Mt. Meteorol. Res., 36, 46-52, 2016 (in Chinese).

Zhang, D., Cong, Z., Ni, G., Yang, D., and Hu, S.: Effects of snow ratio on annual runoff within the Budyko framework, Hydrol. Earth Syst. Sci., 19, 1977-1992, https://doi.org/10.5194/hess-19-1977-2015, 2015.

Zhang, Y. and Ma, N.: Spatiotemporal variability of snow cover and snow water equivalent in the last three decades over Eurasia, J. Hydrol., 559, 238-251, https://doi.org/10.1016/j.jhydrol.2018.02.031, 2018.

850 Zhang, Y., Hao, Z., Xu, C., and Lai, X.: Response of melt water and rainfall runoff to climate change and their roles in controlling streamflow changes of the two upstream basins over the Tibetan Plateau, Hydrol. Res., 51, 272-289, https://doi.org/10.2166/nh.2019.075, 2020.

Zhang, Y., Ishikawa, M., Ohata, T., and Oyunbaatar, D.: Sublimation from thin snow cover at the edge of the Eurasian cryosphere in Mongolia, Hydrol. Process., 22, 3564-3575, https://doi.org/10.1002/hyp.6960, 2008.

855 Zhao, Q., Ding, Y., Wang, J., Gao, H., Zhang, S., Zhao, C., Xu, J., Han, H., and Shangguan, D.: Projecting climate change impacts on hydrological processes on the Tibetan Plateau with model calibration against the glacier inventory data and observed streamflow, J. Hydrol., 573, 60-81, https://doi.org/10.1016/j.jhydrol.2019.03.043, 2019.

Zhong, K., Zheng, F., Xu, X., and Qin, C.: Discriminating the precipitation phase based on different temperature thresholds in the Songhua River Basin, China, Atmos. Res., 205, 48-59, https://doi.org/10.1016/j.atmosres.2018.02.002, 2018.

Zhou, S., Che, T., and Dai, L.: Based on the type of ground site representative of snow remote sensing products precision evaluation, Remote Sens. Technol. Appl., 32, 228-237, https://doi.org/10.11873/j.issn.1004-0323.2017.2.0228, 2017 (in Chinese).

Zhu, G., Lu, L., Su, Y., Wang, X., Cui, X., Ma, J., He, J., Zhang, K., and Li, C.: Energy flux partitioning and evapotranspiration in a sub-alpine spruce forest ecosystem, Hydrol. Process., 28, 5093-5104, https://doi.org/10.1002/hyp.9995, 2014.

Zhu, L., Zhang, Y., Wang, J., Tian, W., Liu, Q., Ma, G., Kan, X., and Chu, Y.: Downscaling snow depth mapping by fusion of microwave and optical remote-sensing data based on deep learning, Remote Sens., 13, 584, https://doi.org/10.3390/rs13040584, 2021. 